\title{
Tectonics
}

\author{
RESEARCH ARTICLE \\ 10.1029/2019TC005671 \\ Key Points: \\ - Major rift-related faults have \\ reactivated preexisting thrusts or \\ thrusts associated with unroofed \\ folds through negative inversion \\ - Basement structures not only have \\ crucial influence on the rift \\ geometry of the Jianghan Basin but \\ also control its rift localization \\ - The multidirectional basement \\ reactivation and extension with rift \\ localization inspire our \\ understanding of tripartite rift \\ systems
}

Correspondence to:

L. Mei,

lfmei@cug.edu.cn

Citation:

Wu, L., Mei, L., Paton, D. A., Liu, Y., Shen, C., Liu, Z., et al. (2020). Basement structures have crucial influence on rift development: Insights from the Jianghan Basin, central China.

Tectonics, 39, e2019TC005671. https:// doi.org/10.1029/2019TC005671

Received 15 MAY 2019 Accepted 13 JAN 2020 Accepted article online 21 JAN 2020

(C)2020. American Geophysical Union. All Rights Reserved.

\section{Basement Structures Have Crucial Influence on Rift Development: Insights From the Jianghan Basin, Central China}

\author{
Lulu Wu $\mathbf{W}^{1,2} \mathbb{D}$, Lianfu Mei ${ }^{1}$ (D), Douglas A. Paton ${ }^{2}$, Yunsheng Liu ${ }^{3}$, Chuanbo Shen ${ }^{1}$, Zhaoqian Liu ${ }^{1}$, \\ Jin $\mathrm{Luo}^{3}$, Caizheng $\mathrm{Min}^{4}$, Minghua $\mathrm{Li}^{3}$, and Hui $\mathrm{Wen}^{3}$ \\ ${ }^{1}$ Key Laboratory of Tectonics and Petroleum Resources, Ministry of Education, China University of Geosciences, Wuhan, \\ China, ${ }^{2}$ Basin Structure Group, School of Earth and Environment, University of Leeds, Leeds, UK, ${ }^{3}$ Research Institute of \\ Exploration and Development, Jianghan Oilfield Branch Company, SINOPEC, Wuhan, China, ${ }^{4}$ Research Institute, China \\ National Offshore Oil Corporation (CNOOC), Beijing, China
}

\begin{abstract}
Crustal heterogeneity has a fundamental influence on rift development; however, the detailed architecture of structures within crystalline basement is commonly poorly understood, resulting in the exact manner in which basement structures control rift development being rather enigmatic. The Jianghan Basin evolved on a crystalline basement covered by thick prerift strata, providing an excellent opportunity to unravel the enigma. Using extensive 2-D and 3-D seismic, borehole and field data from the Jianghan Basin in combination, we investigate the deformation characteristics of basement structures and unravel their relationship with the overlying rift basin. A most striking feature of the basement structures in the Jianghan Basin is that prerift strata near the major rift-related fault planes in the hanging walls are older than these in the footwalls and for most faults prerift strata in the hanging walls become increasingly older while approaching the fault planes, suggesting that these rift-related faults have reactivated preexisting thrusts or thrusts associated with unroofed folds through negative structural inversion. All the major rift-related faults have very high $\mathrm{D}_{\max } / \mathrm{L}$ ratios $(0.11-0.66)$ compared to typical normal faults, likely resulting from either constant length fault model or low frictional strength. By unraveling the prerift deformation intensity and structural division of basement structures in the Jianghan Basin, we propose that basement structures not only have crucial influence on rift geometry but also control rift localization. The reactivation of multidirectional basement structures and multidirectional extension with rift localization in the Jianghan Basin provides yet unrecognized insights into the development of tripartite rift systems.
\end{abstract}

\section{Introduction}

Rift basins commonly evolve on structurally heterogeneous crust that has undergone numerous deformation events prior to the final phase of extension (e.g., Fazlikhani et al., 2017; Morley, 2014; Mortimer et al., 2016). Numerous studies utilizing a wide variety of techniques have proposed that basement structures play a key role in shaping the geometry of rift basins by controlling basin location and the orientation of major riftrelated faults, for example, using gravity and magnetic data (Katumwehe et al., 2015), seismic and well data (Bird et al., 2015; Fazlikhani et al., 2017; Fossen et al., 2017; Morley, 2014; Mortimer et al., 2016; Paton \& Underhill, 2004; Phillips et al., 2016; Qi et al., 2015; Ye et al., 2018), analogue and numerical modeling (Aanyu \& Koehn, 2011; Autin et al., 2013; Chattopadhyay \& Chakra, 2013; Deng et al., 2017, 2018; Tong et al., 2014), and geochronological and topographic data (Rotevatn et al., 2018; Smets et al., 2016). However, the exact manner in which basement structures reactivate and the degree that basement structures exert their influence on the overlying rift basins remains poorly understood, although some studies have paid attention to the basement structures and their relationship with individual rift-related faults and subbasins (Bird et al., 2015; Fazlikhani et al., 2017; Morley, 2014; Phillips et al., 2016). The primary reason is that rift basins mostly evolve on a crystalline basement which is mainly composed of magmatic and metamorphic rocks (Fazlikhani et al., 2017; Katumwehe et al., 2015; Morley, 2014; Mortimer et al., 2007); therefore, prerift structures are more difficult to identify within crystalline basement than prerift strata (Hou et al., 2010; Paton et al., 2006; Su et al., 2009; Wu, Mei, Liu, et al., 2018). Their differences are especially noticeable when basement structures are thrusts and/or folds. 
As rifting proceeds, the activity of rift-related faults and depocenters generally shows spatial variations, resulting in rifting migration and rift localization (e.g., Bell et al., 2014; Cowie et al., 2005; Gawthorpe et al., 2003; Nixon et al., 2016). Many factors have been discussed in previous studies to decipher these phenomena, such as strain variation and thermal and rheological evolution of lithosphere (Behn et al., 2002; Bell et al., 2014; Gawthorpe et al., 2003; Huismans \& Beaumont, 2007). However, the role of basement structures in these processes remains uncertain. In addition, previous studies have been conducted in rift basins whose major rift-related faults and basement structures are in a relatively uniform direction (e.g., Cape Fold Belt, Paton et al., 2006; Erlian Basin, Qi et al., 2015). These cases cannot reconcile the initiation and development of tripartite rift systems and triple junctions which show a complex multidirectional system of riftrelated faults (Acocella, 2014, and references therein; Heine et al., 2013). Consequently, the evolution of tripartite rift systems is still poorly understood.

The Jianghan Basin, located in central China, developed on a crystalline basement covered by thick prerift strata (Figures 1 and 2a; Wang et al., 2006), offering an excellent opportunity to investigate the role of basement structures during rift development. Moreover, the prerift strata in the Jianghan Basin are well exposed in the surrounding area (Figures $1 \mathrm{~b}$ and 1c), which can be used to constrain basement structures in conjunction with the extensive 2-D and 3-D seismic and borehole subsurface data (Figure 3a). In this study, we aim to (a) investigate the characteristics of rift-related fault system and basement structures in the Jianghan Basin, (b) clarify the evolution of rift-related faults and depocenters, (c) document the relationship between basement structures and overlying rift basin, and (d) provide a new insight into the development of tripartite rift systems. Our study, for the first time, provides an exceptional image of faults exhibiting negative structural inversion (namely rift-related deformation reactivating preexisting reverse faults) that is globally unrivaled. Our investigation of the evolution of the Jianghan Basin provides a fundamentally new insight into how strain is distributed at rift initiation in a multidirectional system and subsequently localized. This reveals the importance of basement inheritance on establishing tripartite rift systems and the early development of triple junctions during continental breakup.

\section{Geological Setting}

The Jianghan Basin, located on the northern South China Block, is a large Cretaceous-Cenozoic petroliferous rift basin, covering an area of $34,000 \mathrm{~km}^{2}$ (Figures $1 \mathrm{a}$ and $1 \mathrm{~b}$ ). The basin is bound by the Qinling-Dabie orogenic belt to the north and east, the Jiangnan Orogen to the south and the Huangling massif to the northwest. Notably, much of the North Jianghan Basin outcrops on the surface with a series of predominantly NNW-striking grabens and half-grabens (Figures $1 \mathrm{~b}$ and 1c). In contrast to the North Jianghan Basin, the central Jianghan Basin and South Jianghan Basin are buried by less than 1,100-m thick postrift sediments (Figures $1 \mathrm{~b}$ and 2a; Wu, Mei, Liu, et al., 2018). The Jianghan Basin is surrounded by a prerift fold and thrust belt without extensional reactivation (Figures $1 \mathrm{~b}$ and 1c).

The basement of the Jianghan Basin consists of two parts: the underlying crystalline basement and the overlying prerift strata (Figures $2 \mathrm{a}$ and $2 \mathrm{~b}$ ). The crystalline basement of the Jianghan Basin mainly consists of Archean-Proterozoic metamorphic and metasedimentary rocks (Henan Bureau of Geology and Mineral Resources [HBGMR], 1990). The prerift strata refer to the Sinian (Ediacaran)-Jurassic sequences with alternating deposition of carbonate and detrital rocks and can be subdivided into four units (Figure 2a). During the Sinian to the Early Triassic, the Jianghan Basin was located on the passive continental margin of the northern South China Block and was covered by widespread carbonate platform and marine clastic deposits (HBGMR, 1990; Yao et al., 2015). The tectonic setting changed in the mid-Late Triassic due to the collision of the South China Block and North China Craton (Dong et al., 2011), resulting in foreland detrital sedimentation in the Jianghan area.

The Sinian succession, with a maximum thickness of $1,000 \mathrm{~m}$, is dominantly composed of limestones and dolomites with conglomerates at the base. The approximately 1,200-m thick Cambrian-Ordovician sequences mainly consist of limestones, dolomites, argillaceous dolomites, and marine shales. The overlying Silurian unit having a maximum thickness of 2,300 $\mathrm{m}$ is characterized by mudstones, silty mudstones, and muddy siltstones, while the Devonian sequences that are less than $50 \mathrm{~m}$ thick are mainly composed of quartz sandstones and are absent throughout most of the Jianghan area. The depositional facies varied from open 

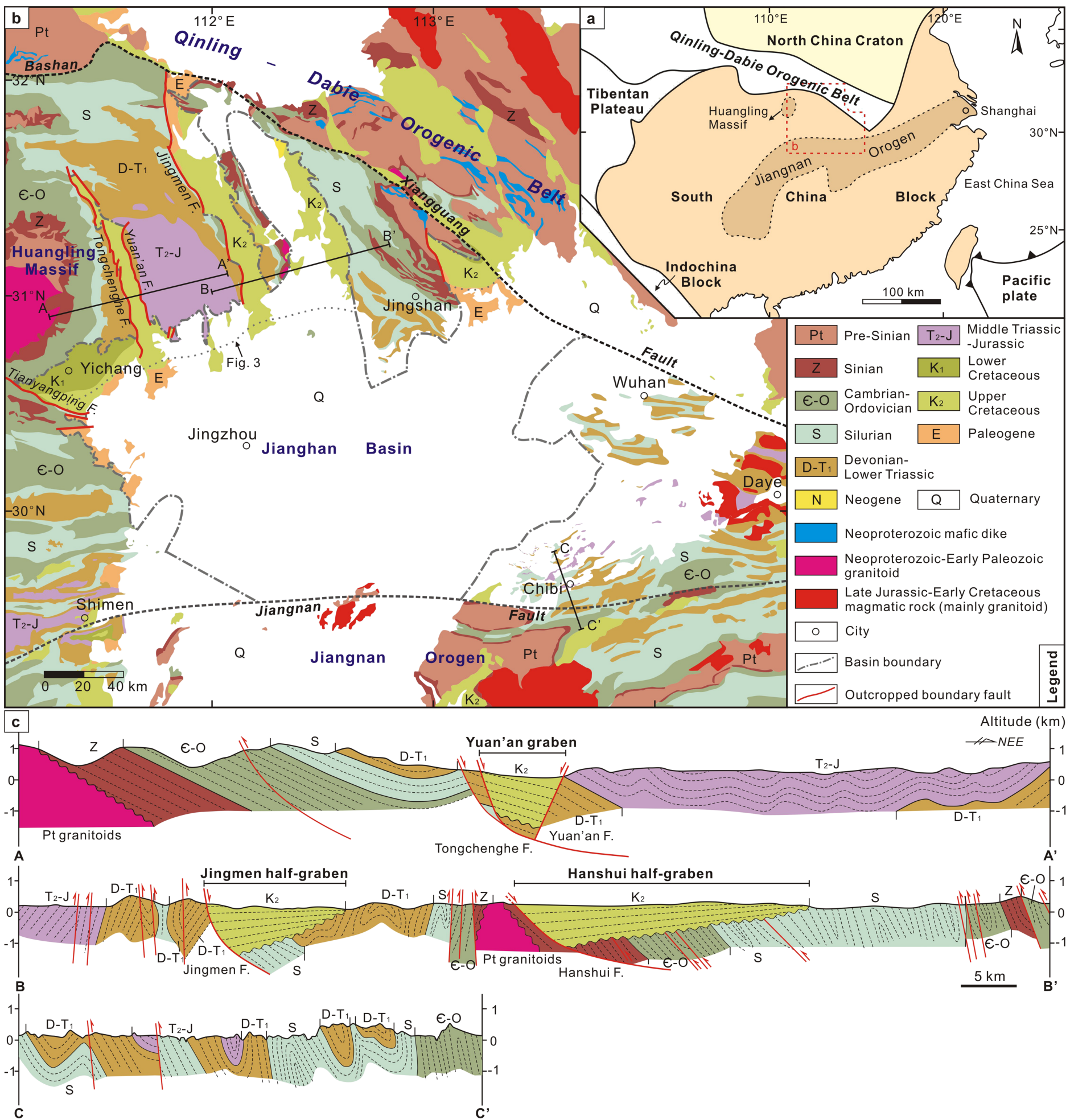

Figure 1. (a) Tectonic map showing the location of the Jianghan Basin. (b) Geological map of the Jianghan area (modified after HBGMR, 1988, 1989, 1990). (c) Cross sections showing the architecture of the North Jianghan Basin and the deformation characteristics of the Chibi fold belt (modified from Shi et al., 2013; ZM, 1976; PM, 1976).

platform during the Cambrian-Ordovician to littoral and shoreland during the Silurian-Devonian. The very thin Devonian sequences are always attributed to the overlying unit rather than the underlying Silurian unit following the Hercynian movement (e.g., Wang et al., 2013). The Carboniferous to Lower Triassic sediments 


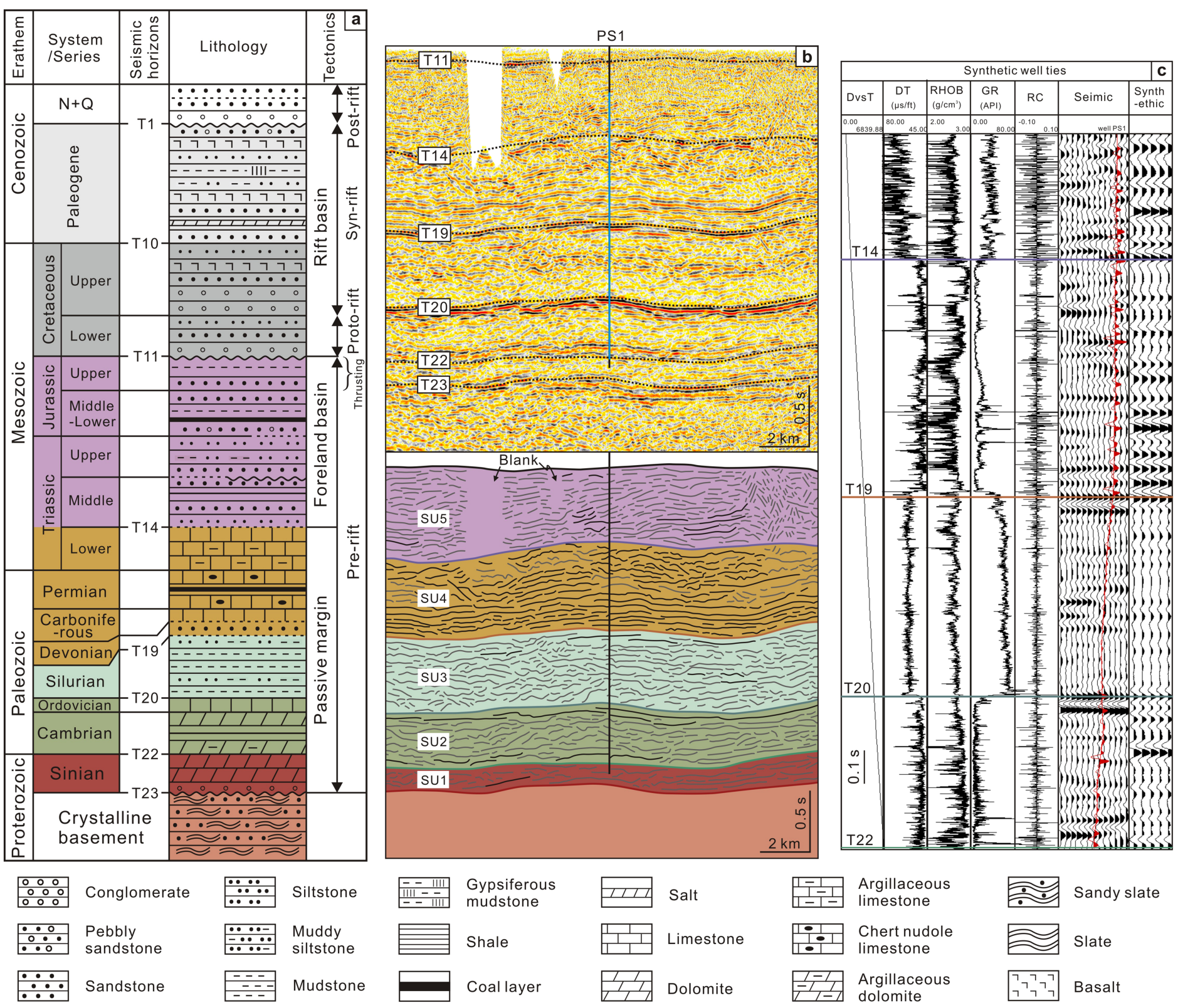

Figure 2. (a) Stratigraphic column for the Jianghan Basin (modified from HBGMR, 1990; Wu, Mei, Liu, et al., 2018). (b) Characteristics of basement reflections and seismic units. (c) Seismic well tie of well PS1. Seismic Unit 1 (SU1): thin, medium-low amplitude, semicontinuous, and medium frequency reflections; Seismic Unit 2 (SU2): thickened, medium-low amplitude, semicontinuous, and medium frequency reflections; Seismic Unit 3 (SU3): thickened, medium-low amplitude, chaotic-semicontinuous, and medium frequency reflections; Seismic Unit (SU4): thickened, medium-high amplitude, continuous-semicontinuous, and medium frequency reflections; Seismic Unit 5 (SU5): thickened, medium-low amplitude, chaotic-semicontinuous, and high-medium frequency reflections. See Figures 3b and 5 for location.

were deposited in a shallow-water environment as indicated by the presence of many coal layers (HBGMR, 1990; Shu et al., 2008). This succession mainly comprises limestones, chert nodule limestones, and argillaceous limestones, with a maximum thickness of 2,400 m. The Middle Triassic-Jurassic foreland sediments mainly consists of terrestrial conglomerates, sandstones, and mudstones, interbedded with coal layers.

Widespread thrusting and folding occurred in the Jianghan area during the Late Jurassic as the QinlingDabie orogenic belt thrust southwestward and the Jiangnan Orogen thrust northwestward (Liu et al., 2005, 2015). The compressional event was caused by a combination of the continued convergence between the South China Block and North China Craton and northwestward subduction of the Pacific plate (Liu 

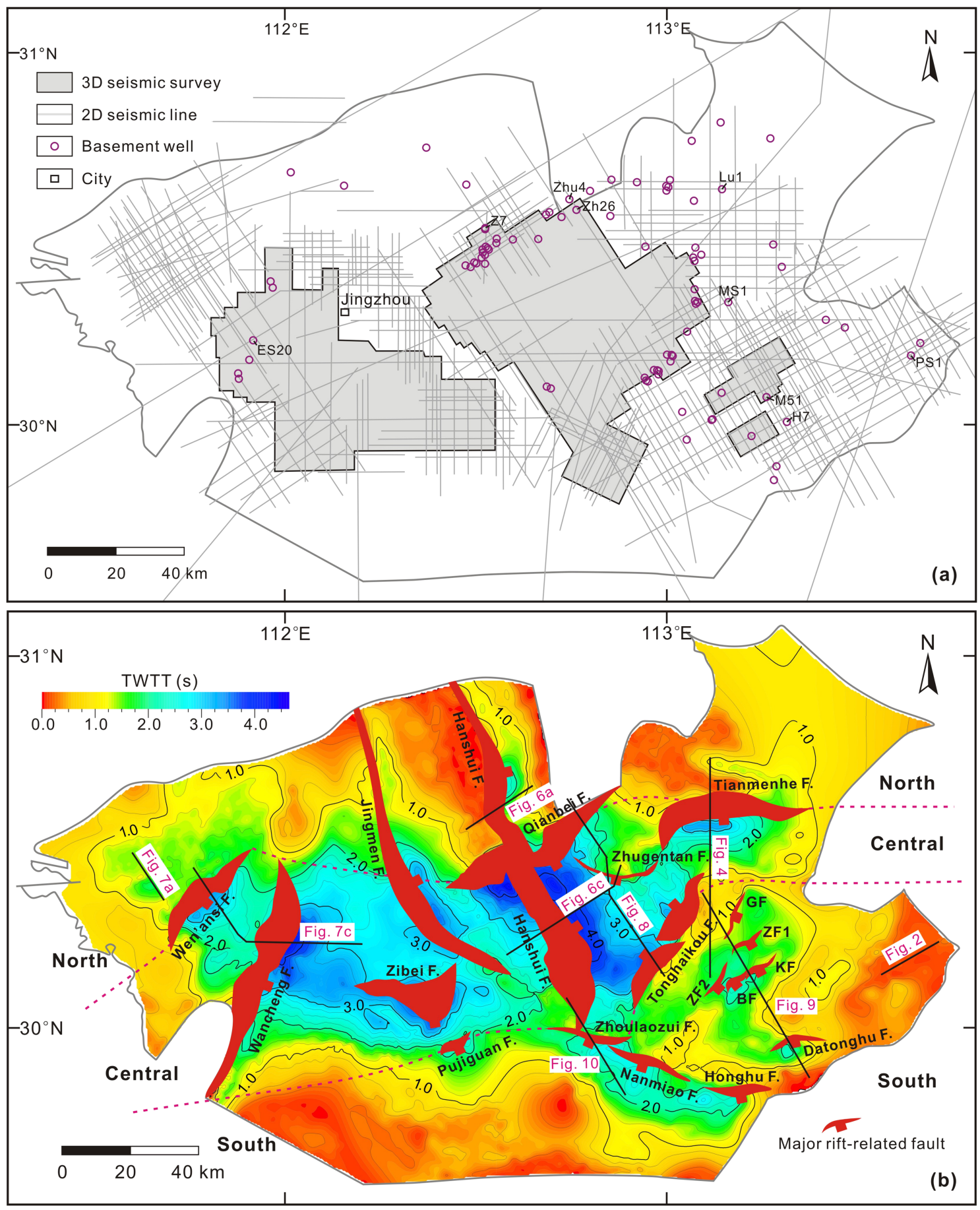

Figure 3. (a) Map showing the coverage of seismic data and the locations of basement wells used in this study. (b) Time structure map of base rift surface with the major rift-related faults offsetting seismic basement. The width of fault polygons is proportional to the heave of the faults. Fault names: GF, Guohe Fault; ZF, Zhanggou Fault; KF, Kaixiantai Fault.

et al., 2015; Zhang et al., 2009). As a result, a series of thrust and fold belts formed in the Jianghan area, many of which are visible on the geological map (Figure 1b), namely the NNW- to NW-trending belt in the northwest, the NNE- to ENE-trending belt in the south, and the arc-shaped belt in the northwest. The superposition of these belts formed a complex converging zone between them which is mostly covered by the Cretaceous-Cenozoic sediments (Figure 1b; Liu et al., 2015). 
The Late Jurassic thrust faults and folds underwent extensionally reactivated through the Late Cretaceous and Paleogene rifting events, after the Early Cretaceous thermal doming (Mei et al., 2008; Wu, Mei, Liu, et al., 2018). The driving mechanism of the rifting events was the active upwelling of upper mantle induced by a combination of the rollback of the Pacific slab and India-Asia collision ( $\mathrm{Li}$ et al., 2014, Li, Zhu, et al., 2015; Liu et al., 2004; Wu, Mei, Liu, et al., 2018, Wu, Mei, Paton, et al., 2018). During the Paleogene, the rift-related faults in the North Jianghan Basin gradually aborted while most faults in the central and South Jianghan Basin were further extensionally reactivated with some newly reactivated faults (Wu, Mei, Liu, et al., 2018, Wu, Mei, Paton, et al., 2018). The Late Cretaceous syn-rift sediments are dominated by conglomerates, sandstones, mudstones, and some basalt eruptions, with a maximum thickness of $\sim 4,500 \mathrm{~m}$. The Paleogene sediments are mainly sandstones, mudstones, salt, and voluminous basalts (Figure 2a; Wang et al., 2006), with a maximum thickness of $\sim 9,000 \mathrm{~m}$.

\section{Methodology and Interpretation of Basement Structures}

The dataset used in this study includes 2-D seismic lines (>8,000 km), 3-D seismic surveys (ca. 5,000 km²), borehole data and field data (Figure 3a). The 2-D seismic lines have a line spacing of 1 to $7 \mathrm{~km}$. The 3-D seismic surveys have a 12.5-, 25-, or 50-m inline and crossline spacing. These seismic data have high quality of imaging within the prerift strata, allowing for imaging to depths of 6-s two-way travel time (TWTT). A total of 86 wells have penetrated the basement (Figure 3a), which were used for constraining prerift stratigraphic horizons. The interpretation of syn-rift sequences has been summarized by Wu, Mei, Paton, et al. (2018). The time-depth conversion formula is Depth $(\mathrm{m})=0.0003 * \mathrm{~T}^{2}+0.9368^{*} \mathrm{~T}$ (T-Time, ms/TWTT) for calculating fault displacements and dips (Wu, Mei, Paton, et al., 2018). Fault displacements were calculated with heave and throw values.

Interpretation of prerift strata and basement structures is based on seismic-well ties and seismic reflection characteristics (Figures 2 and 4). Top basement map is presented (Figure 3b), as are appropriate seismic sections to validate the observations and interpretation in this study although individual isochron maps between key seismic horizons cannot be shown because of data confidentiality. The Sinian (Ediacaran)Jurassic strata are divided by several medium-high amplitudes, semicontinuous-continuous reflections (key seismic horizons), defining five distinct seismic units (Figures $2 \mathrm{~b}$ and 4 ). The top unit is always truncated by the base rift surface, so its thickness can be much thinner than the underlying unit. The Sinian unit is characterized by Seismic Unit 1 (SU1) with a thin package (170-270 ms thick) of medium-low amplitude, semicontinuous, and medium frequency reflections. The overlying Cambrian-Ordovician unit is characterized by Seismic Unit 2 (SU2) with a thickened package (400-480 ms thick) of medium-low amplitude, semicontinuous, and medium frequency reflections. The Silurian unit is characterized by Seismic Unit 3 (SU3), which displays a thickened package (590-620 ms thick) of medium-low amplitude, chaotic-semicontinuous, and medium frequency reflections. The Devonian-Lower Triassic unit is characterized by Seismic Unit 4 (SU4), which displays a thickened package (650-720 ms thick) of medium-high amplitude, continuoussemicontinuous, and medium frequency reflections. The Middle Triassic-Jurassic unit is characterized by Seismic Unit 5 (SU5), displaying a thickened package (600-820 ms thick) of medium-low amplitude, chaotic-semicontinuous, and medium-high frequency reflections. Among them, SU3 and SU4 are most typical and recognizable throughout the basin.

Based on the seismic reflections and borehole data, the basement structures and their interactions with riftrelated faults can be identified and unraveled (Figures $4 \mathrm{a}$ and $4 \mathrm{~b}$ ). The prerift strata in the hanging wall (near the fault plane) not only are older than these in the footwall but also become increasingly older while approaching the fault plane. To visually show the prerift deformation styles of the basement structures, structural restoration was undertaken using Midland Valley's 2D Move software (Figure 4c). We used a layer cake model in the depth conversion. Interval velocities for the prerift strata were calculated in well PS1; velocity differences are less than $10 \%$ when compared with other basement wells. The velocities for SU1 to SU5 are 4,480,6,270,5,185, 6,600, and 6,600 m/s, respectively. The potential influence of compaction is considered to be negligible as the prerift strata were deeply buried before they underwent thrusting and folding. We applied a simple shear algorithm within 2D Move software to remove the normal displacements and estimate the prerift configuration (Figure 4c). Structural restorations were only performed on faults with large normal displacements. During the restoration, seismic section in Figure 4b have ca. 12.1-km horizontal 


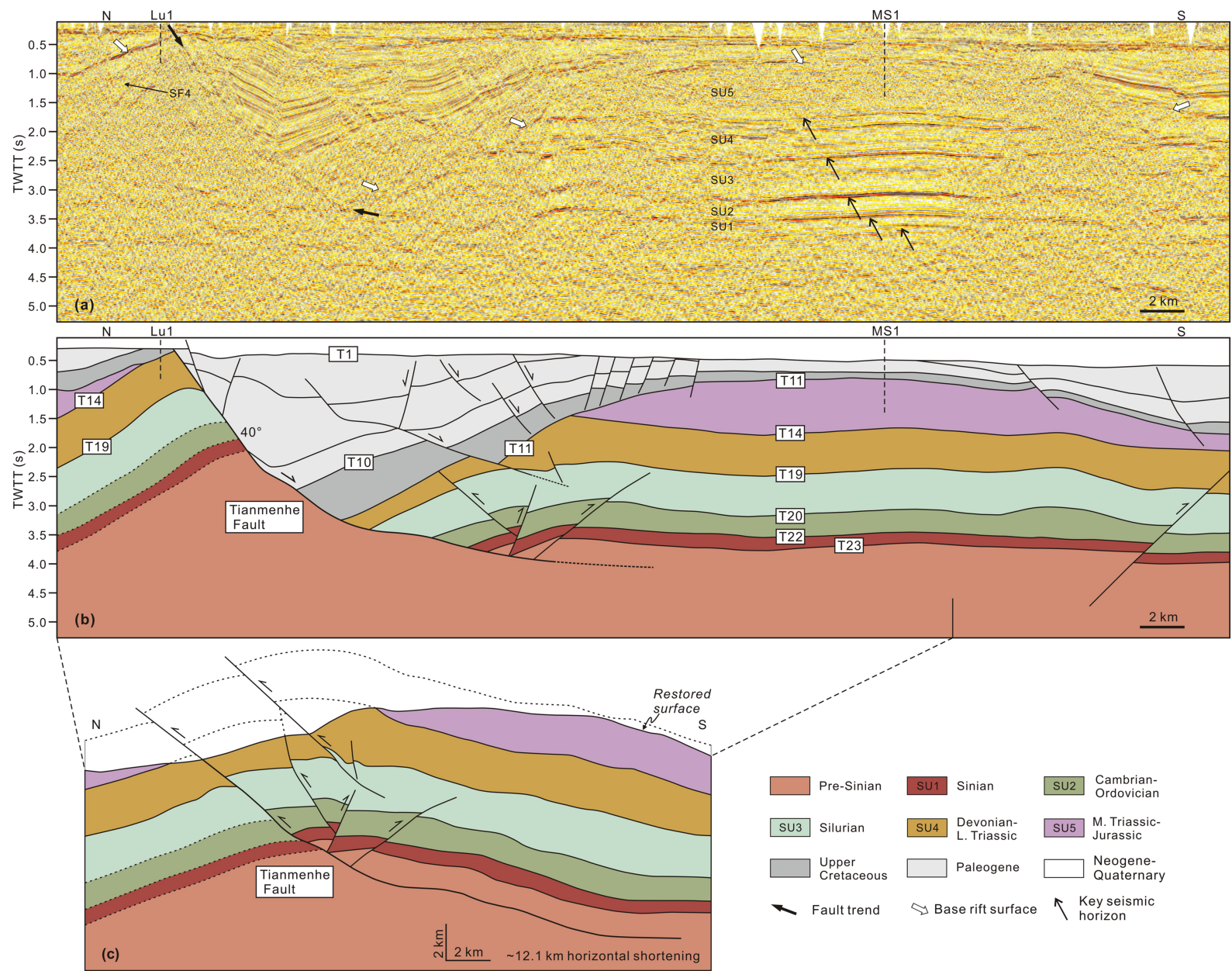

Figure 4. Uninterpreted and interpreted seismic profiles showing the characteristics of basement structures and interactions between basement structures and major rift-related faults, along with the restored section. Well located nearby the section is shown in vertical dashed line. The erosional parts are restored schematically assuming the strata are of equal thickness. See Figures $3 \mathrm{~b}$ and 5 for location.

shortening. Comparing Figure $4 \mathrm{~b}$ with Figure $4 \mathrm{c}$, the removal of the normal displacements along the major rift-related faults reveal that these same faults correspond to a series of thrusts associated with unroofed folds. The restorations reveal apparent compressional displacements on the restored fault planes. The restored geometry is similar to the fold and thrust belt on the southeast margin of the Jianghan Basin as well as the fold and thrust belt in the northern Alpine foreland (Section C- $C^{\prime}$ in Figure 1c; Malz et al., 2016). The general deformation characteristics of the restored section demonstrate that the Jianghan Basin have reactivated preexisting fold and thrust belt and major rift-related faults have reactivated preexisting thrusts or thrusts associated unroofed folds through negative structural inversion.

\section{Characteristics of Rift-Related Fault System and Basement Structures}

The major rift-related faults in the Jianghan Basin show highly variable strikes (Figures 1b, 3b, and 5). Overall, the major rift-related faults can be divided into three groups: 1) the NNW-trending fault system in the North and central Jianghan Basin, 2) the NNE-ENE-trending fault system in the central and South Jianghan Basin, and 3) the WNW to nearly E-W-trending fault system in the central and South Jianghan Basin. Importantly, the NNW-trending faults mainly dip to the ENE and the other major faults mainly dip to the ESE-SW. Using outcrop and subsurface data in combination, the present basement geology of the Jianghan area was mapped (Figure 5). Clearly, basement deformation in the Jianghan area is dominated by a NNW-trending synclinorium and a NNW to E-W-trending synclinorium, being divided by a NNW- 


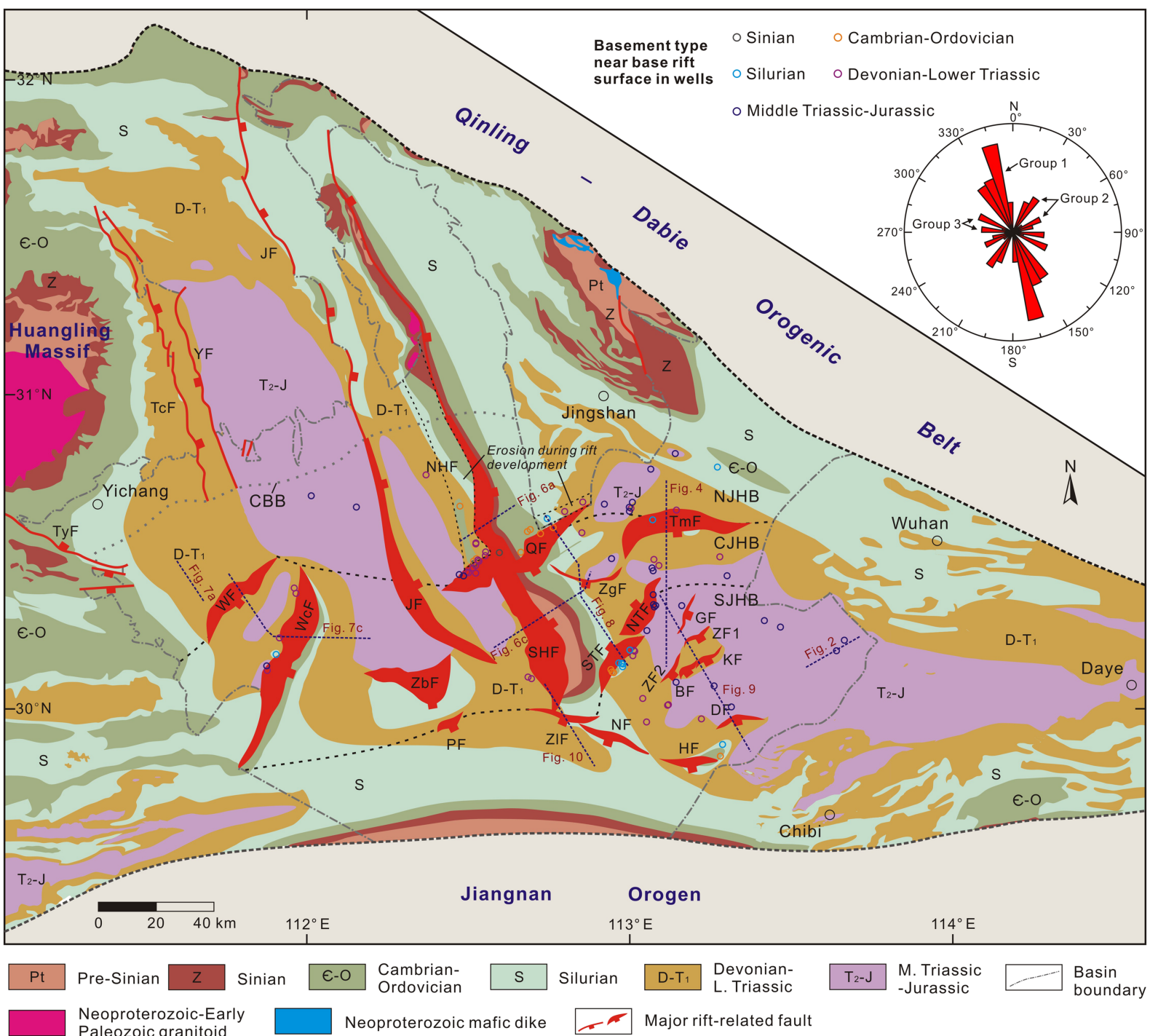

Figure 5. Present basement geological map showing the present deformation characteristics of prerift strata in the Jianghan area. The fault strike data in the inset rose diagram are length-weighted. Fault names: BF, Baimiao Fault; DF, Datonghu Fault; HF, Honghu Fault; JF, Jingmen Fault; KF, Kaixiantai Fault; QF, Qianbei Fault; Typ, Tianyangping Fault; TcF, Tongchenghe Fault; NF, Nanmiao Fault; NHF, northern segment of the Hanshui Fault; SHF, southern segment of the Hanshui Fault; ZgF, Zhugentan Fault; TmF, Tianmenhe Fault; NTF, northern segment of the Tonghaikou Fault; STF, southern segment of the Tonghaikou Fault; GF, Guohe Fault; YF, Yuan'an Fault; WF, Wen'ansi Fault; WcF, Wancheng Fault; ZbF, Zibei Fault; ZF, Zhanggou Fault; ZlF, Zhoulaozui Fault. NJHB, North Jianghan Basin; CJHB, central Jianghan Basin; SJHB, South Jianghan Basin; CBB, Cenozoic basin boundary.

trending narrow anticline (Figure 5). Importantly, the NNE-ENE- and nearly E-W-trending major riftrelated faults in the central and South Jianghan Basin overprint the two synclinoria and NNW-trending faults. In the following sections, we divide the rift-related faults in the Jianghan Basin into three groups and describe the characteristics of rift-related fault system and basement structures in detail.

\subsection{The NNW-Trending Fault System}

The NNW-trending fault system crops out at the surface and is evident in the geological map (Figure 1b), forming a series of NNW-striking grabens and half-grabens (Figures 1b and 1c), except for the WNWtrending Tianyangping graben. Most rift-related faults dip to the ENE, other than the WSW-dipping Yuan'an and NNE-dipping Tianyangping faults. These rift-related faults coincide with the thrusts and folds that also crop out on the surface (Figure 1b; HBGMR, 1990). The Hanshui Fault dips at ca. $20^{\circ}$ with an acute cutoff angle, indicating an initial low-angle normal fault (Figures 6a and 6b). Together with the basement 

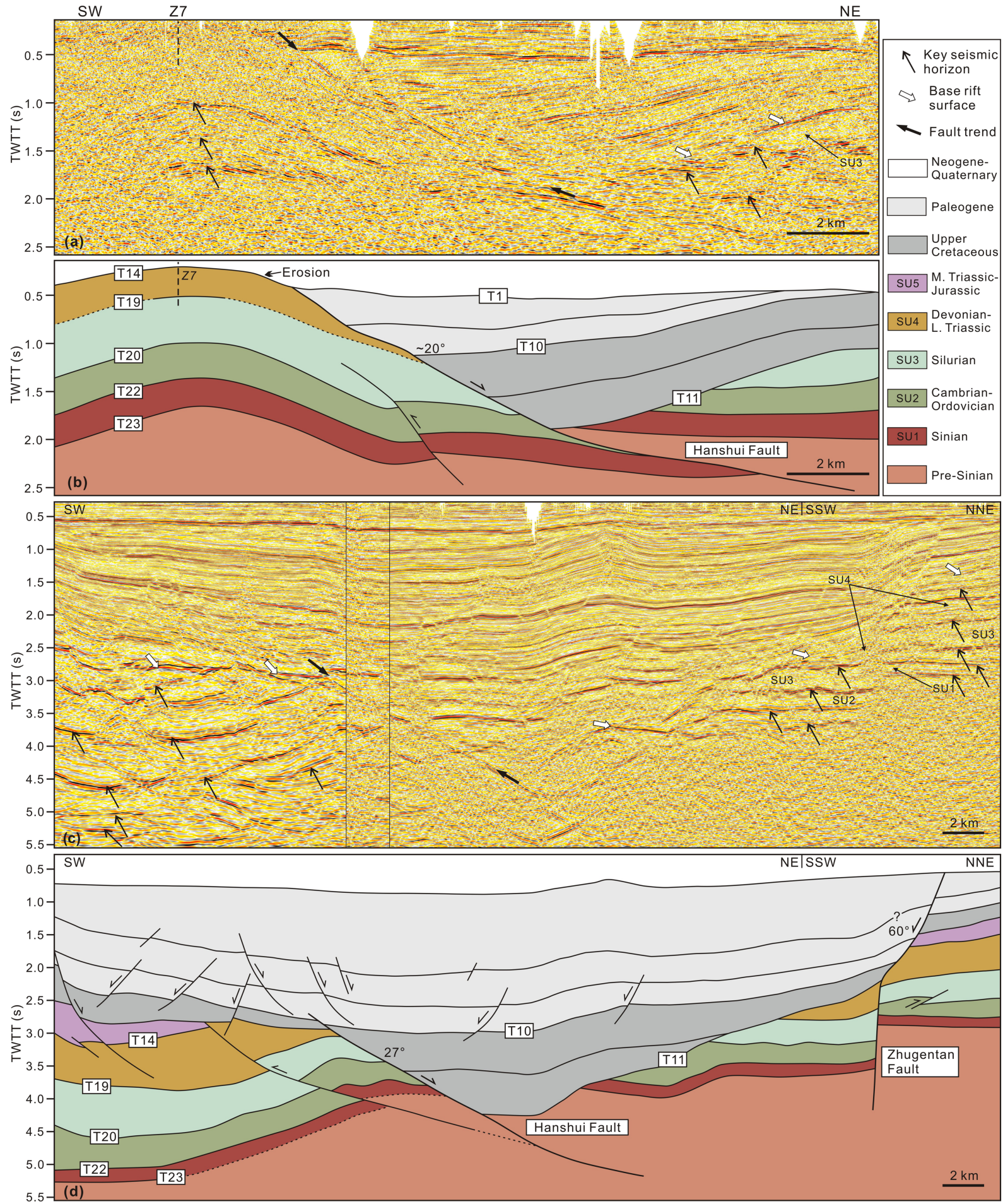

Figure 6. Uninterpreted and interpreted seismic profiles crossing the Hanshui Fault. Well located nearby the section is shown in vertical dashed line. See Figures $3 \mathrm{~b}$ and 5 for locations.

penetrations in $\mathrm{Z7}$ well, basement structures were unraveled. The prerift strata near the rift-related fault plane in the hanging wall of the Hanshui Fault is pre-Sinian crystalline basement, while those in the footwall are the Devonian-Lower Triassic unit (even accounting for the erosion that occurred during rift development), indicating a reverse sense of slip along the fault when the normal displacement is restored. Furthermore, while approaching the fault plane, the prerift strata in the hanging wall change from the 


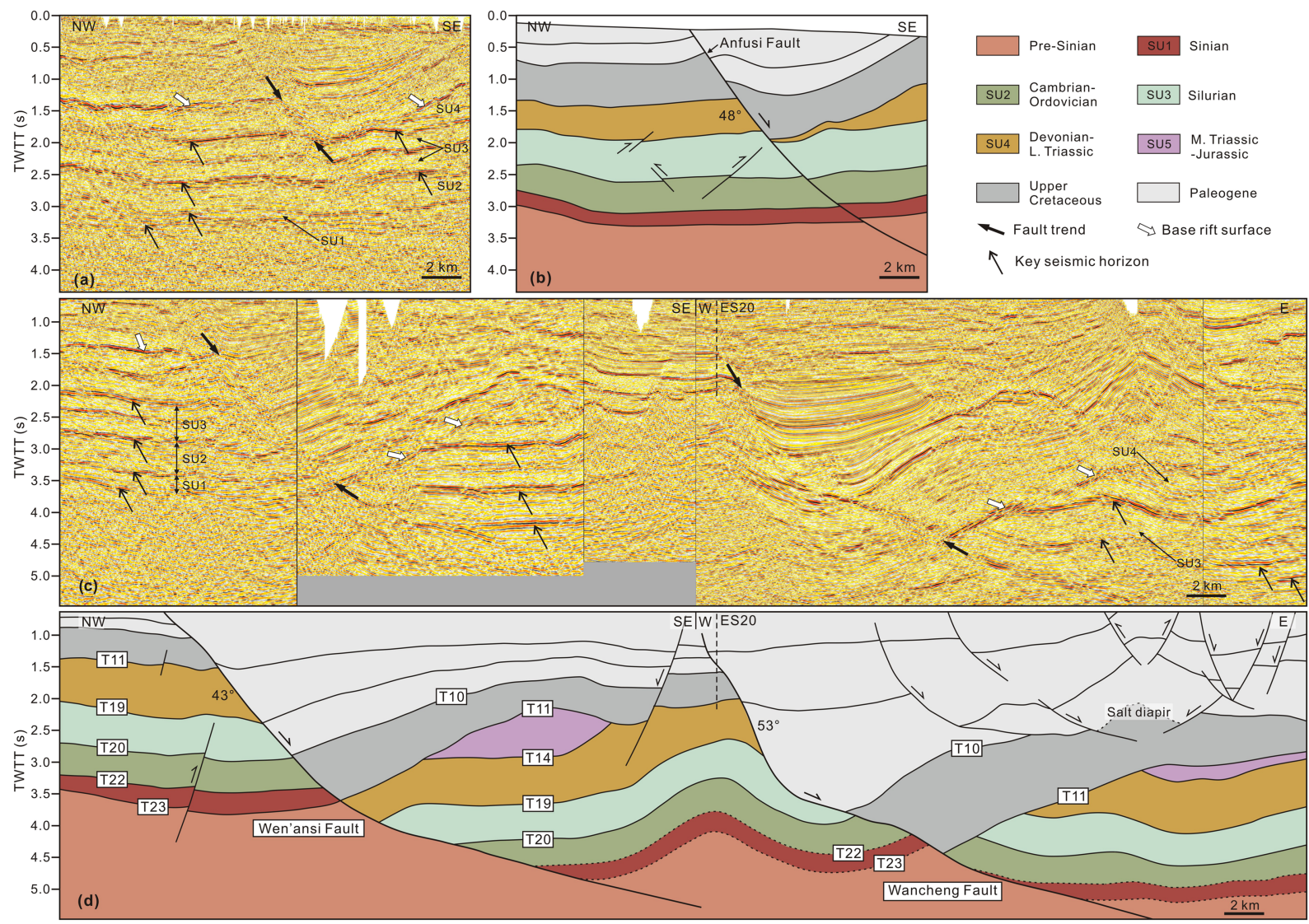

Figure 7. Uninterpreted and interpreted seismic profiles showing the fault system and basement structures in the central west Jianghan Basin. Well located nearby the section is shown in vertical dashed line. See Figures $3 \mathrm{~b}$ and 5 for locations.

Silurian unit to pre-Sinian crystalline basement, indicating that the prerift strata become increasingly older. Therefore, the northern Hanshui Fault have reactivated a thrust associated with an unroofed fold. Notably, there is still some compressional offsets preserved in the lower part of the Hanshui Fault (Figure 6b) within the prerift strata (Figure $6 \mathrm{~b}$ ).

The Qianjiang Fault offsets the Hanshui Fault, dividing it into two segments. The southern segment of the Hanshui Fault had a much greater fault activity rates during the Late Cretaceous and its activity gradually ceased during the earliest Paleogene (Figure 6d). The southern segment of the Hanshui Fault dipping at ca. $27^{\circ}$ is also a low-angle normal fault (Figure $6 \mathrm{~d}$ ), with a maximum displacement of ca. $14.5 \mathrm{~km}$. The prerift strata near the fault planes in the hanging walls of the Hanshui and Zhugentan faults are the pre-Sinian crystalline basement and the Devonian-Lower Triassic unit, which are older than those in the footwalls (the Devonian-Lower Triassic unit and Middle Triassic-Jurassic unit, respectively). As illustrated with the restoration (Figure 4), this geometry would restore to a compressional offset after the removal of the normal displacement. In addition, with proximity to the rift-related fault plane, the prerift strata in the hanging wall of the Hanshui Fault change from the Devonian-Lower Triassic unit to pre-Sinian crystalline basement and become increasingly older (Figure 6d). Thus, the southern segment of Hanshui Fault has reactivated a thrust associated with an unroofed fold and the Zhugentan Fault resulted from the reactivation of a thrust. The lower part of the Zhugentan Fault has a steep and upright geometry (Figure 6d). This geometry and its nearly E-W strike may result from the combination of southwestward and northwestward compression.

\subsection{The NNE-ENE-Trending Fault System}

The Wen'ansi and Wancheng faults located in the central West Jianghan Basin are two NNE-NE-trending listric faults (Figures $3 \mathrm{~b}$ and 5). The Wancheng Fault dips at ca. $50^{\circ}$ in the upper section and has a maximum displacement of ca. 13.5 km (Figure 7d), while the Wen'ansi Fault located in its NW orientation indicates a 

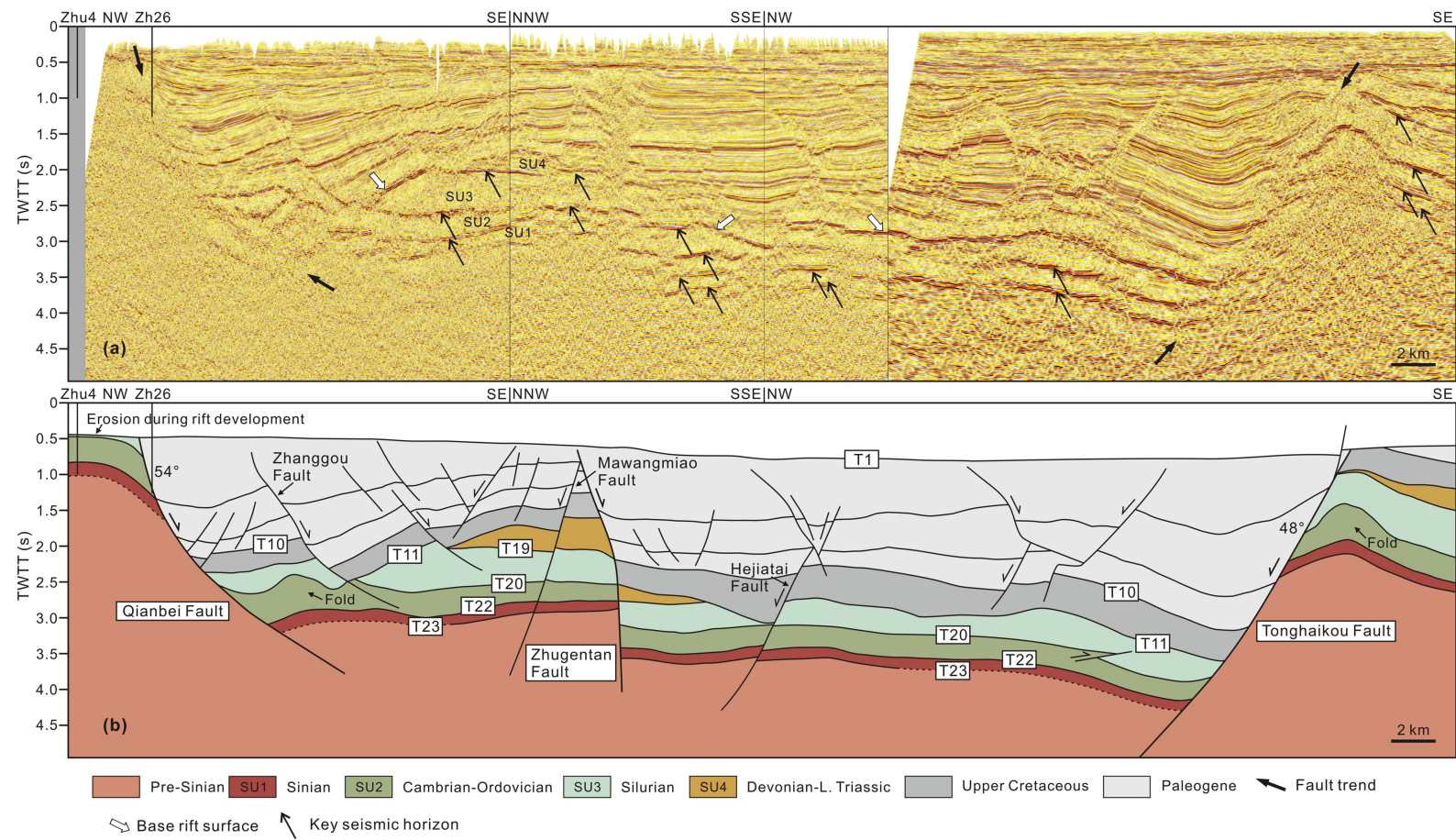

Figure 8. Uninterpreted and interpreted seismic profiles showing the rift-related fault system and basement structures in the central east Jianghan Basin. See Figures $3 \mathrm{~b}$ and 5 for location.

lower cumulative maximum displacement (ca. $8.2 \mathrm{~km}$ ) and dip angle (ca. $43^{\circ}$ ). In addition, the Anfusi Fault, having a much smaller extensional displacement (ca. $2.5 \mathrm{~km}$ ), developed further toward the NW in the North Jianghan Basin (Figure 7b). The prerift strata near the rift-related fault planes in the hanging walls of the three rift-related faults are the Cambrian-Ordovician unit, middle and lower parts of the Devonian-Lower Triassic unit (from SE to NW), while they are older than these in the footwalls, suggesting that there will be compressional offsets when the normal displacements are restored. With increasing proximity to the fault planes, increasingly older trends are observed in the prerift strata in the hanging walls of the three rift-related faults (Figure 7). Hence, the three rift-related faults result from reactivation of thrusts associated with unroofed folds. Furthermore, the three illustrated faults show decreasing extensional and compressional displacements toward the NW (Figure 7).

The NNE-ENE-trending Qianbei and Tonghaikou faults is nearly perpendicular to the NNW-trending Hanshui and Jingmen faults (Figures 3b and 5). The Qianbei and Tonghaikou faults both have a listric geometry with moderate dips (Figure 8). The prerift strata near the fault planes in the hanging wall of the Tonghaikou Fault are the Silurian unit, and those in the footwall are the Devonian-Lower Triassic unit, indicating that there will be a compressional offset when the normal displacement is restored. The Zhugentan Fault also show similar characteristics after normal faulting restoration. Due to the erosion of the prerift strata in the footwall of the Qianbei Fault, there is no significant difference in stratigraphic age between the prerift strata in the hanging wall and footwall (Figures 5 and 8). The notable fold deformation of the Cambrian-Ordovician unit in the hang wall of the Qianbei Fault and footwall of the Tonghaikou Fault may suggest that shale acted as a detachment during the Late Jurassic thrusting and folding (Figures 2a and 8). We proposed that there was also a compressional offset before normal faulting initiated near the Qianbei Fault for the following three reasons: (a) even accounting for the intense erosion during the rift development ( 1,600 m, Wang et al., 2018), prerift strata in the hang wall are still as old as these in the footwall, suggesting that prerift strata in the hang wall were older than those in the footwall before rift initiated or erosion occurred; (b) the distinct difference in deformation style of prerift strata between the hanging wall and footwall may suggest that there was a thrust between the footwall and hang wall; (c) the strike of the Qianbei Fault coincides with the NE-trending folds on the northern margin of the Jianghan Basin (YM, 1976) as well as the NE-trending Zhanggou Fault (see further discussion below). The Zhanggou Fault is a 


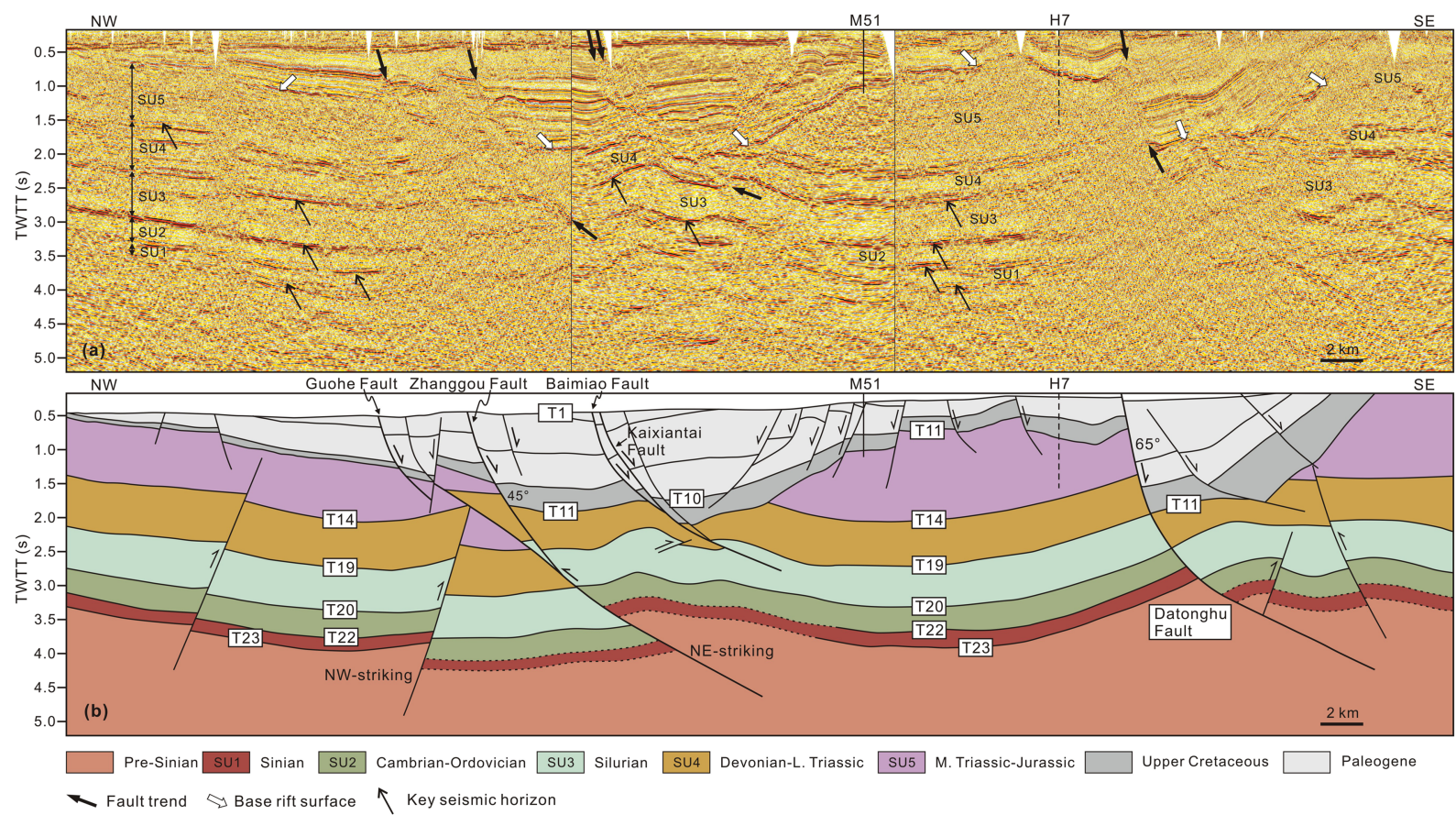

Figure 9. Uninterpreted and interpreted seismic profiles showing the rift-related fault system and basement structures in the south Jianghan Basin. Well located nearby the section is shown in vertical dashed line. See Figures $3 \mathrm{~b}$ and 5 for location.

minor rift-related fault (Figure 8b), and its strike is parallel to the Qianbei Fault. The prerift strata near the Zhanggou fault plane are the Cambrian-Ordovician unit in the hang wall and Sinian unit in the footwall, indicating that there will be a compressional offset when the normal displacement is restored. Furthermore, while approaching the fault plane, the prerift basement strata in the hanging wall change from the Silurian unit to Cambrian-Ordovician unit, becoming increasingly older. Similar characteristics can be also observed near Hejiatai Fault. These features suggest that these minor rift-related faults also result from extensional reactivation of thrusts associated with unroofed folds.

\subsection{The WNW- to Nearly E-W-Trending Fault System}

The WNW- to nearly E-W-trending faults are located in the central and South Jianghan Basin. The Tianmenhe Fault strikes approximately E-W and dips at ca. $40^{\circ}$ in its upper part (Figures 3b, 4b, and 5). The prerift strata near the Tianmenhe fault plane in the hanging wall are the lower part of the Devonian to Lower Triassic unit, which are older than that in the footwall as well Lu1 has penetrated the upper part of the Devonian to Lower Triassic unit (Figure 4b). After normal displacement restoration, there will be a compressional offset (Figure 4c). Furthermore, prerift strata in the hanging wall become increasingly older with proximity to the fault plane as prerift strata change from the Middle Triassic-Jurassic unit to Devonian to Lower Triassic unit. These features suggest that the Tianmenhe Fault has reactivated a thrust fault associated with an unroofed fold.

The NNW-trending Hanshui Fault terminates at the WNW-trending Zhoulaozui Fault (Figures 3b and 5). The Zhoulaozui Fault strikes WNW and dips at $48^{\circ}$ in its upper part (Figure 10). Similar to the above major rift-related faults, the prerift strata in the hanging wall (near the Zhoulaozui fault plane) not only are older than those in the footwall but also become increasingly older while approaching the fault plane, suggesting that there will be a compressional offset and unroofed fold when the normal displacement is restored.

\section{Fault Evolution and Depocenter Development}

\subsection{Normal Fault Displacement Versus Length}

The major rift-related faults of the Jianghan Basin have a large range of displacements (from ca. 1.5 to 14.5 $\mathrm{km}$; Figure 11). Some major rift-related faults have simple displacement patterns with a single displacement 

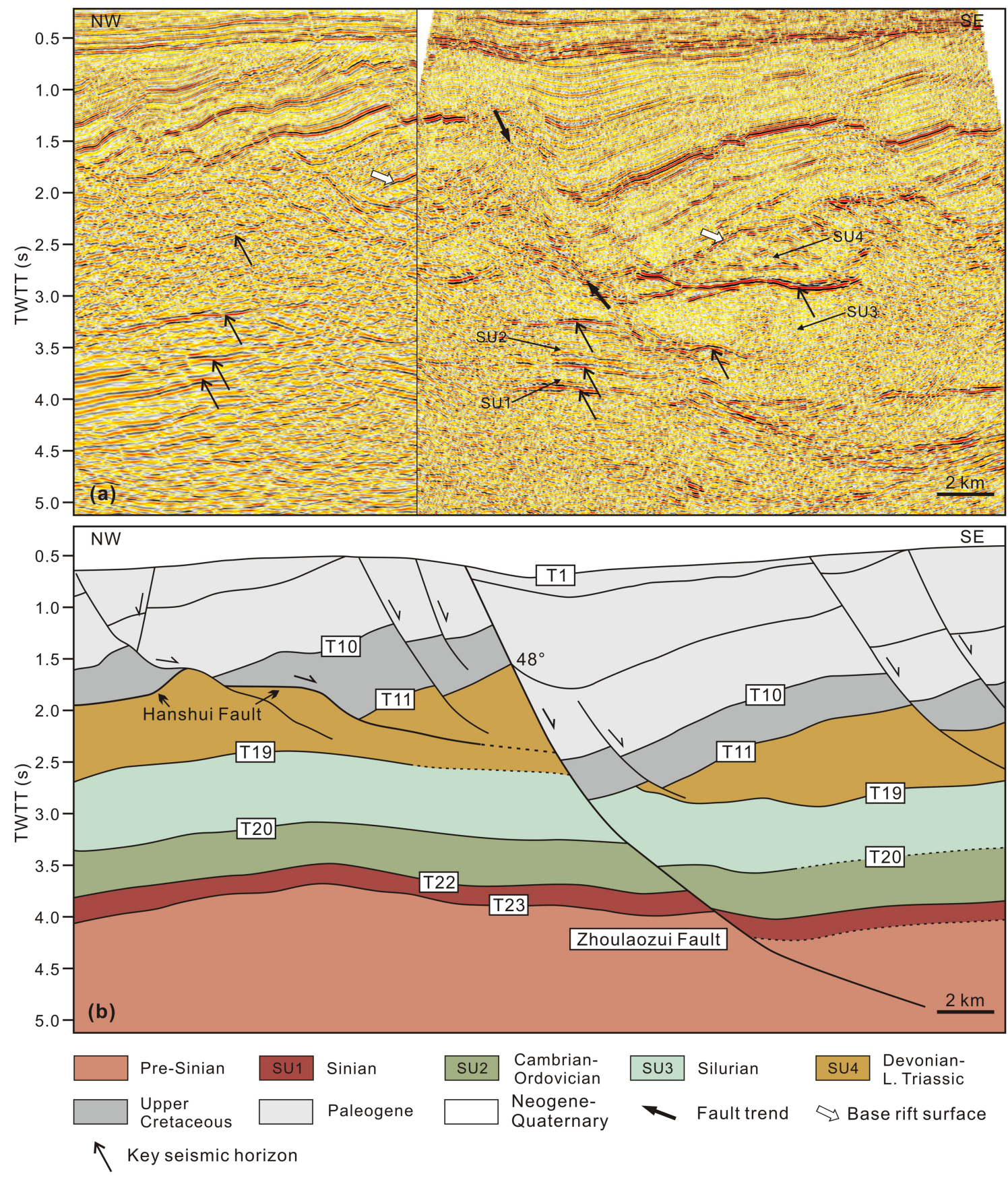

Figure 10. Uninterpreted and interpreted seismic profiles crossing the Zhoulaozui Fault. See Figures $3 \mathrm{~b}$ and 5 for location.

maximum, indicating an isolated fault, while other faults have a complex geometry with multiple local maxima and minima, which suggests the linkage of separate faults (Figures 11a-11f; Morley, 2014). The linear relationship between maximum displacement $\left(\mathrm{D}_{\max }\right)$ and fault length $(\mathrm{L})$ has been widely discussed (Kim \& Sanderson, 2005) and is often used to explore the influence factors of fault growth in many studies (e.g., Exner \& Grasemann, 2010; Grasemann et al., 2011; Schultz et al., 2006; Wibberley et al., 1999, 2000). For faults with multiple linkages, length and displacement data should be measured on every segment when calculating $\mathrm{D}_{\max } / \mathrm{L}$ ratios (see detailed discussion in Morley, 2014). The $\mathrm{D}_{\max } / \mathrm{L}$ ratios of the major rift-related faults in the Jianghan Basin vary from 0.11 to 0.66 . On the lengthmaximum displacement diagram, these major rift-related faults plot above the typical region for normal 

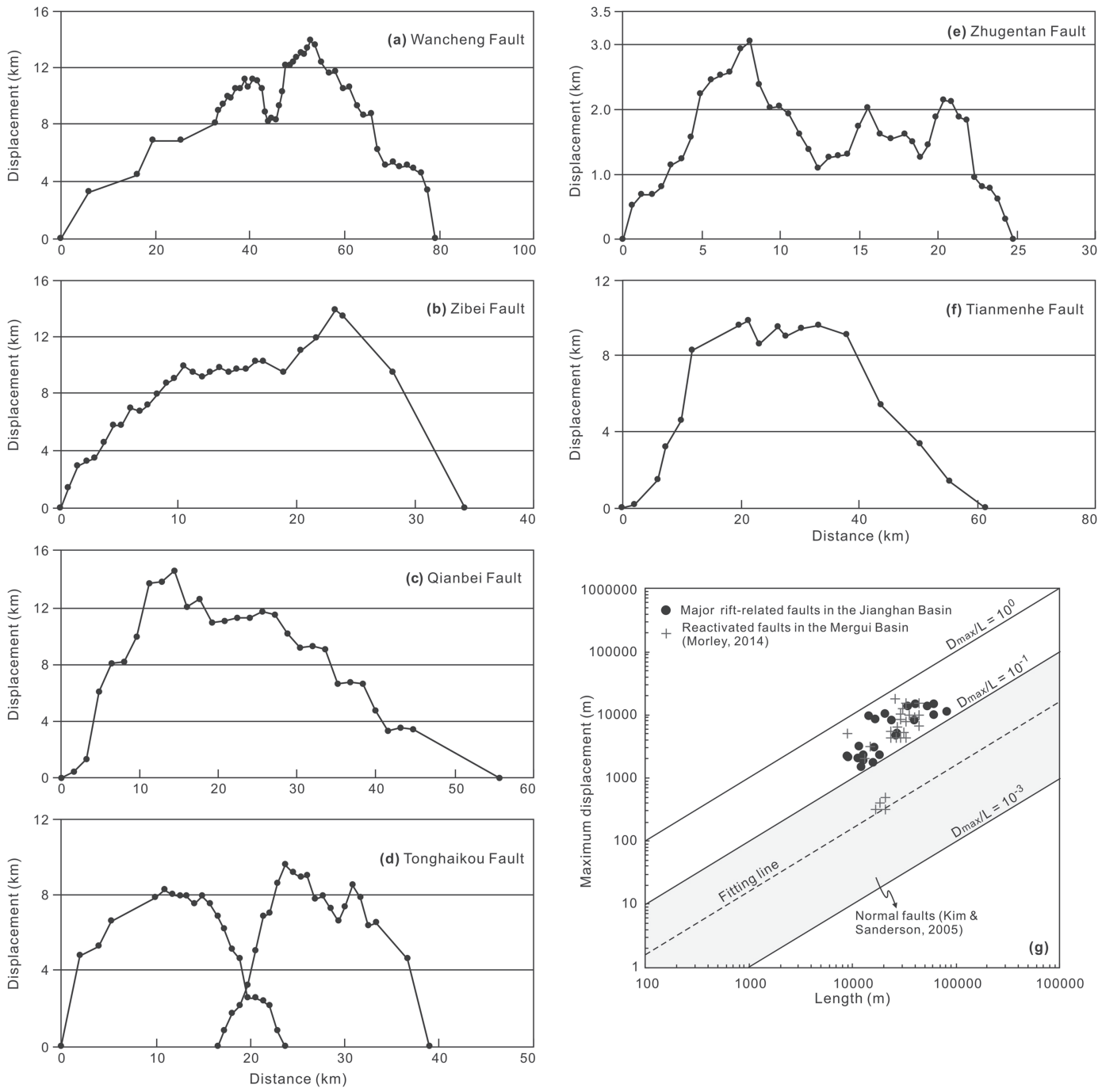

Figure 11. (a-f) Alone-strike variations of fault displacement. (g) Maximum displacement $\left(D_{\max }\right)$ vs. Length (L) diagram for the major faults in the Jianghan Basin, along with the reactivated faults in the Mergui Basin (Morley, 2014) for comparation. The typical $\mathrm{D}_{\max } / \mathrm{L}$ ratios for normal faults are between 0.1 and 0.001 based on Kim and Sanderson (2005).

faults $\left(D_{\max } / \mathrm{L}=0.1-0.001\right.$; Kim \& Sanderson, 2005) and plot in the similar region of the reactivated lowangle normal faults in Thailand (Morley, 2014) (Figure 11g). This may indicate that reactivated faults generally have very high $D_{\max } / L$ ratios.

\subsection{Rift Localization}

The two-phase rifting in the Jianghan Basin has distinct rift architecture and fault systems (Figure 12). During the late Cretaceous initial rifting phase, the depocenters of the Jianghan Basin are widely distributed (Figure 12a). The maximum thickness of sediments in the central Jianghan Basin $(\sim 4,500 \mathrm{~m})$ is moderately thicker than that of the other subbasins $(\sim 3,300 \mathrm{~m})$. As rifting proceeded, the activity of most major riftrelated faults in the North Jianghan Basin ceased during the Paleogene (Figure 12b). Meanwhile, the major rift-related faults in the central and South Jianghan Basin underwent further extension. Notably, the central Jianghan Basin localized the maximum depocenters, and the maximum thickness of its sediments $(\sim 9,000$ $\mathrm{m})$ is significantly thicker than that of the other subbasins $(\sim 2800 \mathrm{~m})$. Therefore, the central Jianghan Basin localized the maximum depocenters and rifting progressively focused in it with the rift development. These phenomena are the typical characteristics of rift localization. 


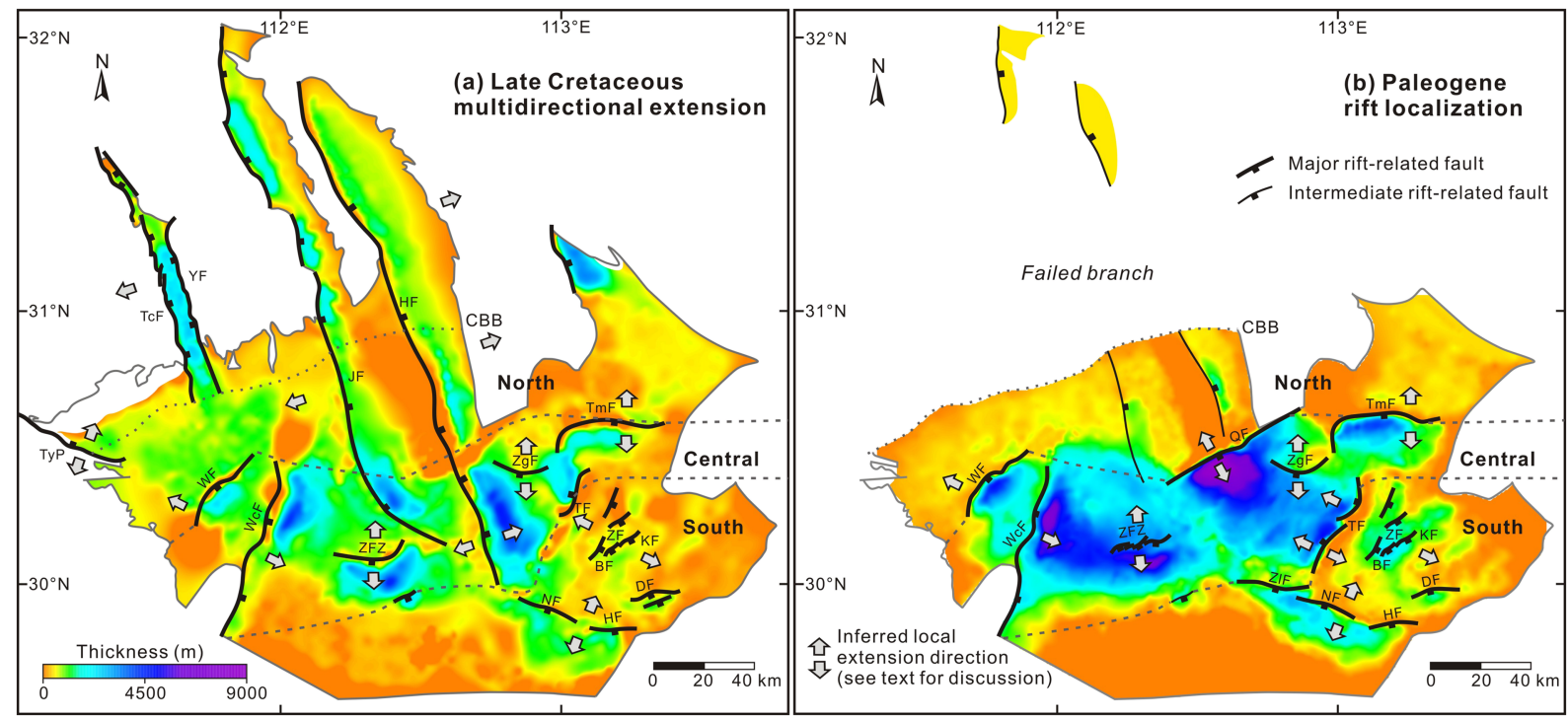

Figure 12. Structural and vertical thickness maps illustrating that basement structures have crucial influence on the rift localization in the Jianghan Basin. CBB, Cenozoic basin boundary. Fault nomenclature is as in Figure 5. The local extension directions are shown schematically and nearly orthogonal to reactivated faults, as they should have a strike angle greater than $60^{\circ}$ relative to preexisting thrust faults in a fully reactivated scenario (see detailed discussion in Deng et al., 2018).

\section{Discussion}

\subsection{Prerift Deformation Intensity and Structural Division of Basement Structures}

Based on the above observations, we reconstruct the nature of the fold and thrust belt prior to the rift phase and outline the spatial variations in intensity and structural domains of the basement structures (Figure 13). The deformation of the prerift strata in the Jianghan area is dominated by the arc-shaped Southern QinlingDabie Thrust Belt, with two wide synclinoriums being divided by a narrow NNW-trending anticline. The arc-shaped Southern Qinling-Dabie Thrust Belt was overprinted by the arc-shaped Huangling Thrust Belt in the west and the linear-shaped northern Jiangnan Thrust Belt in the south, suggesting that the Qinling-Dabie orogenic belt migrated southwestward before the Jiangnan Orogen migrated northwestward (cf. Liu et al., 2015). This conclusion is further verified by the following observations. The NNW-trending Hanshui Fault is truncated by NE-trending Qianbei Fault (Figure 5). In addition, in the South Jianghan Basin, a NW-striking thrust fault is truncated by a NE-striking thrust fault in the prerift strata (Figure 9).

After the collision between the South China Block and North China Craton during the mid-Late Triassic (Dong et al., 2011), the Late Triassic-Middle Jurassic foreland basin formed in the Jianghan area prior to widespread Late Jurassic thrusting and folding (Liu et al., 2015). These tectonic events correspond to the later phase of the Wilson cycle which suggests that there is continued convergence on subducted plate after ocean closure and continental collision (Allen \& Allen, 2005; Wilson, 1966). Thus, we infer that the southwestward extrusion of the Qinling-Dabie orogenic belt during the Late Jurassic is related to the continued convergence between the South China Block (subducted plate) and North China Craton, likely driven by the slab pull from eclogitized mafic crust (c.f. Dong et al., 2013; Li, Dong, et al., 2015). Nevertheless, the Late Jurassic northwestward compression in the Jianghan area is a part of the NE-NNE-trending broad (1,300-km wide) intracontinental orogeny in the South China Block (Zhang et al., 2009), resulting from the northwestward subduction of the Pacific plate.

As the Northern Jiangnan Thrust Belt propagated northwestward, it superimposed the Southern QinlingDabie Thrust Belt which had already formed, resulting in an Interfering and Converging Zone being formed between them (Figure 13). In the Interfering and Converging Zone, there are some south dipping faults with WNW to nearly E-W strikes (especially in its central part), suggesting a combined influence by both southwestward and northwestward compression. We further estimate the basement deformation intensity based on the compressional displacements estimated from restored sections and the superimposed deformation of prerift strata. Based on the estimated deformation intensity and the orientation of thrusts and folds, the 


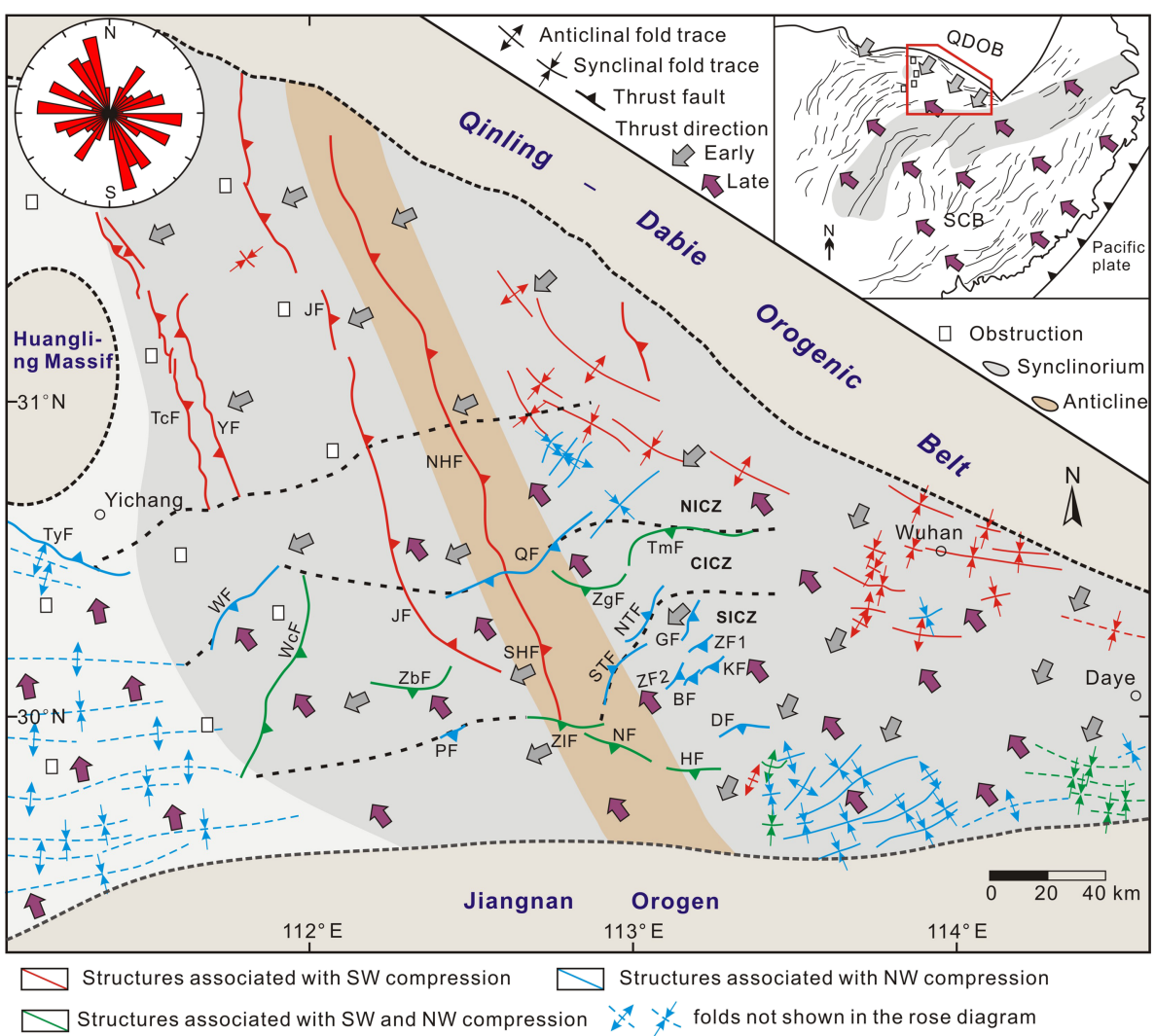

Figure 13. Latest Jurassic tectonic map showing the distribution and structural division of basement structures in the Jianghan area. The inset tectonic map is modified from Li et al. (2014). The fault and fold strike data in the inserted rose diagram are length-weighted. Some folds are not shown in the rose diagram as they are not adjacent to the basin or located in the area with much thicker lithosphere (Li, Zhu, et al., 2015). NICZ, North Interfering and Converging Zone; CICZ, Central Interfering and Converging Zone; SICZ, South Interfering and Converging Zone. Fault nomenclature is as in Figure 5.

Interfering and Converging Zone is divided into three domains (Figure 13): the North Interfering and Converging Zone, Central Interfering and Converging Zone, and South Interfering and Converging Zone. The Central Interfering and Converging Zone show greater strain than the other regions and has the most complicated thrust and fold system.

\subsection{Influence of Basement Structures on Cumulative Displacement and Length}

As shown in Figure 11g, the $\mathrm{D}_{\max } / \mathrm{L}$ ratios of the major rift-related faults in the Jianghan Basin are higher than the typical normal faults, indicating that these faults have higher displacements at a given length. This characteristic may have resulted from either constant length fault model or some other factors (e.g., low frictional strength).

Constant length fault model suggests that faults build displacement with limited growth of fault length after a relatively rapid lengthening stage (e.g., Rotevatn et al., 2019). Previous studies indicate that reactivated faults may grow via constant length fault model (Morley, 2014; Paton, 2006). In this case, when reactivating preexisting basement structures, rift-related faults rapidly propagated following the preexisting thrusts and then ceased when reaching the tips of thrusts (also see discussion in Paton, 2006). When faults undergo further extension, fault displacements rapidly increase, while the increase of fault lengths is very limited. Displacement-length ratios gradually increase and may exceed the typical ratios (0.001-0.1; Kim \& Sanderson, 2005) given an intense rifting. Therefore, the major rift-related faults in the Jianghan Basin have very high $\mathrm{D}_{\max } / \mathrm{L}$ ratios. Paton (2006) and Bell et al. (2014) also discussed the $\mathrm{D}_{\max }-\mathrm{L}$ relationship when basement reactivation occurred. Although their observations were based on an exponential relationship between $D_{\max }$ and L, they are consistent with the results in our studies. 


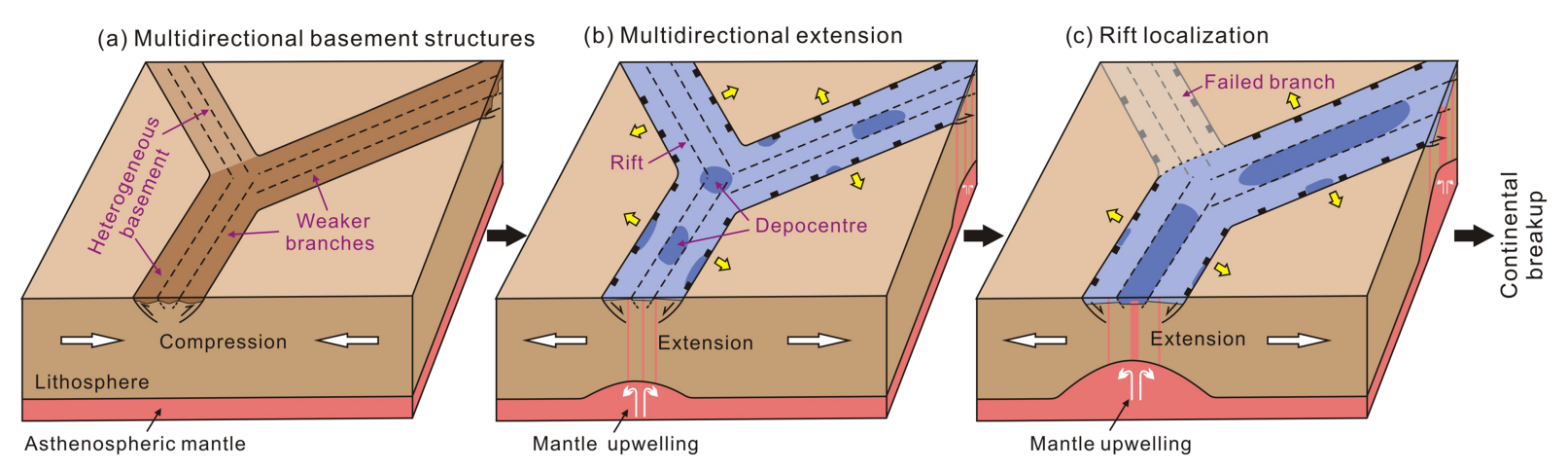

Figure 14. Cartoon diagrams illustrating the potential influence of basement structures on the development of tripartite rift systems during continental rifting.

Low frictional strength can also result in atypical displacement-length ratios. Many studies have argued that the maximum displacement of a fault increases as the frictional strength decreases (Schultz et al., 2006; Wibberley et al., 1999, 2000), which can result in a greater $\mathrm{D}_{\max } / \mathrm{L}$ ratio. This coincides with the very high $\mathrm{D}_{\max } / \mathrm{L}$ ratios in the Jianghan Basin and Mergui Basin (Morley, 2014) compared to the typical normal faults (Figure 11g). Therefore, low frictional strength may also play a significant controlling factors of extensional reactivation of preexisting structures, other than the dip and orientation of basement structures (e.g., Bird et al., 2015; Deng et al., 2018; Fazlikhani et al., 2017). That may be why prerift structures offset by rift-related faults without reactivation despite being favorably oriented with respect to extension direction and with a relatively high dip in some rift basins (Fazlikhani et al., 2017; Phillips et al., 2016).

\subsection{Influence of Basement Structures on Rift Development}

As discussed above, all the major rift-related faults in the Jianghan Basin have extensionally reactivated preexisting thrusts or thrusts associated with unroofed folds in a negative inversion manner. Therefore, basement structures control the geometry of the Jianghan Basin, including its location, shape, and architecture, through controlling the development of major rift-related faults (Figures 12 and 13). There are three significant phenomena during the development of the Jianghan Basin. First, the maximum depocenters during the Late Cretaceous and Paleogene all focused in the central Jianghan Basin, namely the Central Interfering and Converging Zone that underwent more intense deformation than other regions (Figures 12 and 13). Moreover, from the Late Cretaceous to Paleogene, rifting focused in the Interfering and Converging Zone while most major rift-related faults in the North Jianghan Basin (out of the Interfering and Converging Zone) failed. Notably, there is a positive correlation between basement deformation intensity and the thickness of rift sequences and the weakest zone (Central Interfering and Converging Zone) localized the maximum depocenters and rifting progressively focused in it with the rift development (Figures 12 and 13), indicating significant rift localization. These phenomena suggest that the weaker zone is much easier to localize strain. Previous studies have proposed that rift localization can result from strain localization, geothermal gradients, and plastic strain softening (Behn et al., 2002; Gawthorpe et al., 2003; Huismans \& Beaumont, 2007). Through the above discussion, we propose that basement deformation intensity also play an important role in rift localization and narrowing.

Deng et al. (2018) proposed that reactivation occurs when the strike angle of preexisting basement structure to the extension direction is more than $30^{\circ}$ and the strike angle should be greater than $60^{\circ}$ when fully reactivated. In view of the radial strikes of the basement structures and rift-related faults in the Jianghan Basin, we propose that multidirectional extension may be the most effective way to extensional reactivate basement structures in the Jianghan Basin (c.f., Koptev, Gerya, et al., 2018). The multidirectional extension in the Jianghan Basin have been driven by the active upwelling of asthenospheric mantle similar to the Bohai Bay Basin in the North China Craton (Qi \& Yang, 2010; Wu, Mei, Liu, et al., 2018, Wu, Mei, Paton, et al., 2018).

Tripartite rift systems and subsequent triple junctions are an essential component of plate tectonics, commonly associated with continental rifting and the subsequent opening of oceans (e.g., North Sea triple junction, Cowie et al., 2005; Afar triple junction, Acocella, 2014; Gariep tripartite rift system, offshore South 
Africa, Paton et al., 2017). Generally, during the formation of triple junctions, one branch of the tripartite rift systems often progressively fails as rifting proceeds, forming an aulacogen on the passive margin after continental breakup (e.g., Benue Trough, Heine et al., 2013; Ye et al., 2017), or lag behand the other two branches during continental breakup (Afar triple junction, Acocella, 2014; Wolfenden et al., 2004). However, this process remains poorly understood in view of its unique multidirectional extension and rift localization. Notably, these unique features during the formation of triple junctions have a good correspondence with these in the Jianghan Basin. Therefore, we propose a new conceptual model that considers the influence of basement structures on the evolution of tripartite rift systems and triple junctions based on our observations (Figure 14). During the prerift phase, the basement was deformed by multiphase compression from different directions, forming the multidirectional preexisting structures with varying deformation intensity (Figure 14a). Driven by the diapirism of mantle plume or upwelling of asthenospheric mantle, these preexisting thrust faults simultaneously undergo extensional reactivation, forming the tripartite rift system observed (Figure 14b; cf. bidirectional continental breakup and nonuniform splitting, Koptev, Cloetingh, et al., 2018, Koptev, Gerya, et al., 2018). As extension continues, the rift system progressively localizes; namely, rifting progressively localizes on the weaker branches as well as the rift axes, while the branch with relatively weaker deformation progressively fails in a similar manner to the North Jianghan Basin (Figures 12 and 14c).

\section{Conclusions}

Using extensive 2-D and 3-D seismic, borehole and field data from the Jianghan Basin in combination, we unravel the deformation characteristics of basement structures and document their relationship with the overlying rift basin. The main conclusions of this study are as follows:

1. The major rift-related faults in the Jianghan Basin show highly variable strikes and can be divided into three groups: the NNW-trending fault system, the NNE-ENE fault system, and the WNW- to nearly EW-trending fault system.

2. The prerift strata near the major rift-related fault planes in the hanging walls of the major rift-related faults are older than these in the footwalls and for most faults prerift strata in the hanging walls also become increasingly older as proximity to the fault planes increases, suggesting that these rift-related faults have reactivated preexisting thrusts or thrusts associated unroofed folds through negative structural inversion.

\section{Acknowledgments}

Thanks to Thomas Phillips, Ken McCaffrey, Casey Nixon, and two anonymous reviewers for their detailed and constructive comments, and Laurent Jolivet and Derek Keir for their editorial assistance. Mohamed Gouiza and Ben Craven are thanked for the useful discussion during drafting this paper. Midland Valley is thanked for the permission to use Move software in the University of Leeds. We are grateful to C.K. Morley for early discussion on fault displacement through emails. This work was financially supported by the Major National Science and Technology Programs, China (2016ZX05026-003-001, 2017ZX05035001-003, 2016ZX05002-006-007), National Natural Science Foundation of China (NSFC Project 41972152), Scientific Research Project of China Petroleum and Chemical Corporation (P14111), and Natural Science Foundation of Hubei Province (2016CFA084). All the data used in this study are listed in the figures and references or archived in Figshare repository (https://figshare.com/s/ 33316d8fac2b1d23fef4).
3. The major rift-related faults in the Jianghan Basin have very high $\mathrm{D}_{\max } / \mathrm{L}$ ratios $(0.11-0.66)$ than the typical normal faults, likely resulting from either constant length fault model or low frictional strength.

4. The deformation of the prerift strata in the Jianghan area was dominated by the arc-shaped Southern Qinling-Dabie Thrust Belt which was overprinted by the arc-shaped Huangling Thrust Belt in the west and the linear-shaped Northern Jiangnan Thrust Belt in the south, forming a complex multidirectional system of basement structures with an Interfering and Converging Zone.

5. Basement structures not only have crucial influence on the rift geometry of the Jianghan Basin (including its location, shape, and architecture) but also play an important role in rift localization. The weakest Central Interfering and Converging Zone localized the maximum depocenters and rifting progressively focused in it as rifting proceeded, while the region out of the interfering and converging zone progressively failed.

6. The reactivation of multidirectional preexisting basement structures and multidirectional extension with rift localization in the Jianghan Basin provide an important analogue for us in understanding the development of tripartite rift systems during continental rifting.

\section{References}

Aanyu, K., \& Koehn, D. (2011). Influence of pre-existing fabrics on fault kinematics and rift geometry of interacting segments: Analogue models based on the Albertine Rift (Uganda), Western Branch-East African Rift System. Journal of African Earth Sciences, 59(2-3), 168-184. https://doi.org/10.1016/j.jafrearsci.2010.10.003

Acocella, V. (2014). Structural control on magmatism along divergent and convergent plate boundaries: Overview, model, problems. EarthScience Reviews, 136, 226-288. https://doi.org/10.1016/j.earscirev.2014.05.006

Allen, P. A., \& Allen, J. R. (2005). Basin analysis: Principles and applications (pp. 12-14). Oxford London: Blackwell Publishing. 
Autin, J., Bellahsen, N., Leroy, S., Husson, L., Beslier, M., \& D'Acremont, E. (2013). The role of structural inheritance in oblique rifting: Insights from analogue models and application to the Gulf of Aden. Tectonophysics, 607, 51-64. https://doi.org/10.1016/j. tecto.2013.05.041

Behn, M. D., Lin, J., \& Zuber, M. T. (2002). A continuum mechanics model for normal faulting using a strain-rate softening rheology: Implications for thermal and rheological controls on continental and oceanic rifting. Earth and Planetary Science Letters, 202(3-4), 725-740. https://doi.org/10.1016/S0012-821X(02)00792-6

Bell, R. E., Jackson, C. A. L., Whipp, P. S., \& Clements, B. (2014). Strain migration during multiphase extension: Observations from the northern North Sea. Tectonics, 33, 1936-1963. https://doi.org/10.1002/2014TC003551

Bird, P. C., Cartwright, J. A., \& Davies, T. L. (2015). Basement reactivation in the development of rift basins: An example of reactivated Caledonide structures in the West Orkney Basin. Journal of the Geological Society, 172(1), 77-85. https://doi.org/10.1144/ jgs2013-098

Chattopadhyay, A., \& Chakra, M. (2013). Influence of pre-existing pervasive fabrics on fault patterns during orthogonal and oblique rifting: An experimental approach. Marine and Petroleum Geology, 39(1), 74-91. https://doi.org/10.1016/j.marpetgeo.2012.09.009

Cowie, P., Underhull, J. R., Behn, M. D., Lin, J., \& Gill, C. E. (2005). Spatio-temporal evolution of strain accumulation derived from multiscale observations of Late Jurassic rifting in the northern North Sea: A critical test of models for lithospheric extension. Earth and Planetary Science Letters, 234(3-4), 401-419. https://doi.org/10.1016/j.epsl.2005.01.039

Deng, C., Gawthorpe, R. L., Finch, E., \& Fossen, H. (2017). Influence of a pre-existing basement weakness on normal fault growth during oblique extension: Insights from discrete element modeling. Journal of Structural Geology, 105, 44-61. https://doi.org/10.1016/j. jsg.2017.11.005

Deng, C., Gawthorpe, R. L., Fossen, H., \& Finch, E. (2018). How does the orientation of a preexisting basement weakness influence fault development during renewed rifting? Insights from three-dimensional discrete element modeling. Tectonics, 37(7), 2221-2242. https:// doi.org/10.1029/2017TC004776

Dong, S., Gao, R., Yin, A., Guo, T., Zhang, Y., Hu, J., et al. (2013). What drove continued continent-continent convergence after ocean closure? Insights from high-resolution seismic-reflection profiling across the Daba Shan in central China. Geology, 41(6), 671-674. https://doi.org/10.1130/G34161.1

Dong, Y., Zhang, G., Neubauer, F., Liu, X., Genser, J., \& Hauzenberger, C. (2011). Tectonic evolution of the Qinling orogen, China: Review and synthesis. Journal of Asian Earth Sciences, 41, 213-237. https://doi.org/10.1016/j.jseaes.2011.03.002

Exner, U., \& Grasemann, B. (2010). Deformation bands in gravels: Displacement gradients and heterogeneous strain. Journal of the Geological Society, 167(5), 905-913. https://doi.org/10.1144/0016-76492009-076

Fazlikhani, H., Fossen, H., Gawthorpe, R. L., Faleide, J. I., \& Bell, R. E. (2017). Basement structure and its influence on the structural configuration of the northern North Sea rift. Tectonics, 36(6), 1151-1177. https://doi.org/10.1002/2017TC004514

Fossen, H., Khani, H. F., Faleide, J. I., Ksienzyk, A. K., \& Dunlap, W. J. (2017). Post-Caledonian extension in the West Norway-northern North Sea region: The role of structural inheritance. Geological Society, London, Special Publications, 439(1), 465-486. https://doi.org/ 10.1144/SP439.6

Gawthorpe, R. L., Jackson, C. A. L., Young, M. J., Sharp, I. R., Moustafa, A. R., \& Leppard, C. W. (2003). Normal fault growth, displacemen localisation and the evolution of normal fault populations: The Hammam Faraun fault block, Suez rift, Egypt. Journal of Structural Geology, 25(6), 883-895. https://doi.org/10.1016/S0191-8141(02)00088-3

Grasemann, B., Exner, U., \& Tschegg, C. (2011). Displacement-length scaling of brittle faults in ductile shear. Journal of Structural Geology, 33(11), 1650-1661. https://doi.org/10.1016/j.jsg.2011.08.008

HBGMR (Henan Bureau of Geology and Mineral Resources) (1989). Regional Geology of the Henan Province. Beijing: Geological Press. (in Chinese with English summary)

HBGMR (Hubei Bureau of Geology and Mineral Resources) (1990). Regional Geology of the Hubei Province. Beijing: Geological Press. (in Chinese with English summary)

HBGMR (Hunan Bureau of Geology and Mineral Resources) (1988). Regional Geology of the Hunan Province. Beijing: Geological Press. (in Chinese with English summary)

Heine, C., Zoethout, J., \& Muller, R. D. (2013). Kinematics of the South Atlantic rift. Solid Earth, 4(2), 215-253. https://doi.org/10.5194/se4-215-2013

Hou, X., Wu, Z., \& Li, W. (2010). Development characteristics of Mesozoic negative inversion structures in Jiyang depression. Journal of China University of Petroleum, 34(1), 18-23. (in Chinese with English abstract)

Huismans, R. S., \& Beaumont, C. (2007). Roles of lithospheric strain softening and heterogeneity in determining the geometry of rifts and continental margins. Geological Society, London, Special Publications, 282(1), 111-138. https://doi.org/10.1144/SP282.6

Katumwehe, A. B., Abdelsalam, M. G., \& Atekwana, E. A. (2015). The role of pre-existing Precambrian structures in rift evolution: The Albertine and Rhino grabens, Uganda. Tectonophysics, 646, 117-129. https://doi.org/10.1016/j.tecto.2015.01.022

Kim, Y., \& Sanderson, D. J. (2005). The relationship between displacement and length of faults: A review. Earth-Science Reviews, 68(3-4), 317-334. https://doi.org/10.1016/j.earscirev.2004.06.003

Koptev, A., Cloetingh, A., Gerya, T., Calais, E., \& Leroy, S. (2018). Non-uniform splitting of a single mantle plume by double cratonic roots: Insight into the origin of the central and southern East African Rift System. Terra Nova, 30, 125-134. https://doi.org/ $10.1111 /$ ter.12317

Koptev, A., Gerya, T., Calais, E., Leroy, S., \& Burov, E. (2018). Afar triple junction triggered by plume-assisted bi-directional continental break-up. Scientific Reports, 8(1), 14742. https://doi.org/10.1038/s41598-018-33117-3

Li, J., Dong, S., Yin, A., Zhang, Y., \& Shi, W. (2015). Mesozoic tectonic evolution of the Daba Shan Thrust Belt in the southern Qinling orogen, central China: Constraints from surface geology and reflection seismology. Tectonics, 34(8), 1545-1575. https://doi.org/10.1002/ $2014 \mathrm{TC} 003813$

Li, J., Zhang, Y., Dong, S., \& Johnston, S. T. (2014). Cretaceous tectonic evolution of South China: A preliminary synthesis. Earth-Science Reviews, 134, 98-136. https://doi.org/10.1016/j.earscirev.2014.03.008

Li, X., Zhu, P., Kusky, T. M., Gu, Y., Peng, S., Yuan, Y., \& Fu, J. (2015). Has the Yangtze craton lost its root? A comparison between the North China and Yangtze cratons. Tectonophysics, 655, 1-14. https://doi.org/10.1016/j.tecto.2015.04.008

Liu, M., Cui, X., \& Liu, F. (2004). Cenozoic rifting and volcanism in eastern China: A mantle dynamic link to the Indo-Asian collision? Tectonophysics, 393(1-4), 29-42. https://doi.org/10.1016/j.tecto.2004.07.029

Liu, S., Li, W., Wang, K., Qian, T., \& Jiang, C. (2015). Late Mesozoic development of the southern Qinling-Dabieshan foreland fold-thrust belt, Central China, and its role in continent-continent collision. Tectonophysics, 644-645, 220-234. https://doi.org/10.1016/j. tecto.2015.01.015 
Liu, S., Steel, R., \& Zhang, G. (2005). Mesozoic sedimentary basin development and tectonic implication, northern Yangtze Block, eastern China: Record of continent-continent collision. Journal of Asian Earth Sciences, 25(1), 9-27. https://doi.org/10.1016/j.jseaes.2004.01.010 Malz, A., Madritsch, H., Meier, B., \& Kley, J. (2016). An unusual triangle zone in the external northern Alpine foreland (Switzerland): Structural inheritance, kinematics and implications for the development of the adjacent Jura fold-and-thrust belt. Tectonophysics, 670, 127-143. https://doi.org/10.1016/j.tecto.2015.12.025

Mei, L., Dai, S., Shen, C., \& Tang, J. (2008). Formation and disintegration of Mesozoic-Cenozoic intracontinental ramp zone in Middle and Lower Yangtze Region. Geological Science and Technology Information, 27, 1-7. (in Chinese with English abstract)

Morley, C. K. (2014). The widespread occurrence of low-angle normal faults in a rift setting: Review of examples from Thailand, and implications for their origin and evolution. Earth-Science Reviews, 133, 18-42. https://doi.org/10.1016/j.earscirev.2014.02.007

Mortimer, E., Paton, D. A., Scholz, C. A., Strecker, M. R., \& Blisniuk, P. (2007). Orthogonal to oblique rifting: Effect of rift basin orientation in the evolution of the North basin, Malawi Rift, East Africa. Basin Research, 19(3), 393-407. https://doi.org/10.1111/j.13652117.2007.00332.x

Mortimer, E. J., Paton, D. A., Scholz, C. A., \& Strecker, M. R. (2016). Implications of structural inheritance in oblique rift zones for basin compartmentalization: Nkhata Basin, Malawi Rift (EARS). Marine and Petroleum Geology, 72, 110-121. https://doi.org/10.1016/j. marpetgeo.2015.12.018

Nixon, C. W., McNeill, L. C., Bull, J. M., Bell, R. E., Gawthorpe, R. L., Henstock, T. J., et al. (2016). Rapid spatiotemporal variations in rift structure during development of the Corinth Rift, central Greece. Tectonics, 35(5), 1225-1248. https://doi.org/10.1002/2015TC004026

Paton, D. A. (2006). Influence of crustal heterogeneity on normal fault dimensions and evolution: Southern South Africa extensional system. Journal of Structural Geology, 28(5), 868-886. https://doi.org/10.1016/j.jsg.2006.01.006

Paton, D. A., Macdonald, D. I. M., \& Underhill, J. R. (2006). Applicability of thin or thick skinned structural models in a region of multiple inversion episodes: Southern South Africa. Journal of Structural Geology, 28(11), 1933-1947. https://doi.org/10.1016/j. jsg.2006.07.002

Paton, D. A., Mortimer, E. J., Hodgson, N., \& van der Spuy, D. (2017). The missing piece of the South Atlantic jigsaw: When continental break-up ignores crustal heterogeneity. Geological Society, London, Special Publications, 438(1), 195-210. https://doi.org/10.1144/ SP438.8

Paton, D. A., \& Underhill, J. R. (2004). Role of crustal anisotropy in modifying the structural and sedimentological evolution of extensional basins: The Gamtoos Basin, South Africa. Basin Research, 16(3), 339-359. https://doi.org/10.1111/j.1365-2117.2004.00237.x

Phillips, T. B., Jackson, C. A., Bell, R. E., Duffy, O. B., \& Fossen, H. (2016). Reactivation of intrabasement structures during rifting: A case study from offshore southern Norway. Journal of Structural Geology, 91, 54-73. https://doi.org/10.1016/j.jsg.2016.08.008

PM (Puqi Map). (1976). 1:200 000 Geological Map of the People's Republic of China, Puqi Region (in Chinese).

Qi, J., \& Yang, Q. (2010). Cenozoic structural deformation and dynamic processes of the Bohai Bay basin province, China. Marine and Petroleum Geology, 27(4), 757-771. https://doi.org/10.1016/j.marpetgeo.2009.08.012

Qi, J., Zhao, X., Li, X., Yang, M., Xiao, Y., Yu, F., \& Dong, Y. (2015). The distribution of early Cretaceous faulted-sags and their relationship with basement structure within Erlian Basin. Earth Science Frontiers, 22(3), 118-128. (in Chinese with English abstract)

Rotevatn, A., Jackson, C. A. L., Tvedt, A. B. M., Bell, R. E., \& Blakkan, I. (2019). How do normal faults grow? Journal of Structural Geology, 125, 174-184. https://doi.org/10.1016/j.jsg.2018.08.005

Rotevatn, A., Kristensen, T. B., Ksienzyk, A. K., Wemmer, K., Henstra, G. A., Midtkandal, I., et al. (2018). Structural inheritance and rapid rift-length establishment in a multiphase rift: The East Greenland rift system and its Caledonian orogenic ancestry. Tectonics, 37, 1858-1875. https://doi.org/10.1029/2018TC005018

Schultz, R. A., Okubo, C. H., \& Wilkins, S. J. (2006). Displacement-length scaling relations for faults on the terrestrial planets. Journal of Structural Geology, 28(12), 2182-2193. https://doi.org/10.1016/j.jsg.2006.03.034

Shi, W., Dong, S., Ratschbacher, L., Tian, M., Li, J., \& Wu, G. (2013). Meso-Cenozoic tectonic evolution of the Dangyang Basin, northcentral Yangtze craton, central China. International Geology Review, 55, 382-396. https://doi.org/10.1080/00206814.2012.715732

Shu, L., Faure, M., Wang, B., Zhou, X., \& Song, B. (2008). Late Palaeozoic-Early Mesozoic geological features of South China: Response to the Indosinian collision events in Southeast Asia. Comptes Rendus Geoscience, 340, 151-165.

Smets, B., Delvaux, D., Ross, K. A., Poppe, S., Kervyn, M., d'Oreye, N., \& Kervyn, F. (2016). The role of inherited crustal structures and magmatism in the development of rift segments: Insights from the Kivu basin, western branch of the East African Rift. Tectonophysics, 683, 62-76. https://doi.org/10.1016/j.tecto.2016.06.022

Su, J., Zhu, W., Lu, H., Xu, M., Yang, W., \& Zhang, Z. (2009). Geometry styles and quantification of inversion structures in the Jiyang depression, Bohai Bay Basin, eastern China. Marine and Petroleum Geology, 26(1), 25-38. https://doi.org/10.1016/j. marpetgeo.2007.08.003

Tong, H., Koyi, H., Huang, S., \& Zhao, H. (2014). The effect of multiple pre-existing weaknesses on formation and evolution of faults in extended sandbox models. Tectonophysics, 626, 197-212. https://doi.org/10.1016/j.tecto.2014.04.046

Wang, B., Chen, Y., Lu, G., \& Liu, J. (2006). Episodic tectonic movement and evolutional characteristics of the Jianghan Basin. Oil Geophysical Prospecting, 41, 226-230. (in Chinese with English abstract)

Wang, D., Mei, L., Liu, Y., Wu, L., Min, C., \& Luo, J. (2018). Mesozoic-Cenozoic episodic subsidence and migration of Jianghan Basin in extensional composite basin-mountain system. Earth Science, 43(11), 4180-4192. (in Chinese with English abstract)

Wang, Y., Fan, W., Zhang, G., \& Zhang, Y. (2013). Phanerozoic tectonics of the South China Block: Key observations and controversies. Gondwana Research, 23, 1273-1305. https://doi.org/10.1016/j.gr.2012.02.019

Wibberley, C. A., Petit, J., \& Rives, T. (1999). Mechanics of high displacement gradient faulting prior to lithification. Journal of Structural Geology, 21(3), 251-257. https://doi.org/10.1016/S0191-8141(99)00006-1

Wibberley, C. A. J., Petit, J., \& Rives, T. (2000). Mechanics of cataclastic 'deformation band' faulting in high-porosity sandstone, Provence. Earth and Planetary Science, 331(6), 419-425. https://doi.org/10.1016/S1251-8050(00)01423-3

Wilson, J. T. (1966). Did the Atlantic close and then re-open? Nature, 211, 676-681.

Wolfenden, E., Ebinger, C., Yirgu, G., Deino, A., \& Ayalew, D. (2004). Evolution of the northern Main Ethiopian rift: Birth of a triple junction. Earth and Planetary Science Letters, 224(1-2), 213-228. https://doi.org/10.1016/j.epsl.2004.04.022

Wu, L., Mei, L., Liu, Y., Paton, D. A., Luo, J., Yu, L., et al. (2018). The stratigraphic and structural record of the Cretaceous Jianghan Basin, central China: Implications for initial rifting processes and geodynamics. Cretaceous Research, 90, 21-39. https://doi.org/10.1016/j cretres.2018.03.028

Wu, L., Mei, L., Paton, D. A., Guo, P., Liu, Y., Luo, J., et al. (2018). Deciphering the origin of the Cenozoic intracontinental rifting and volcanism in eastern China using integrated evidence from the Jianghan Basin. Gondwana Research, 64, 67-83. https://doi.org/10.1016/ j.gr.2018.07.004 
Yao, W., Li, Z., Li, W., Su, L., \& Yang, J. (2015). Detrital provenance evolution of the Ediacaran-Silurian Nanhua foreland basin, South China. Gondwana Research, 28, 1449-1465. https://doi.org/10.1016/j.gr.2014.10.018

Ye, J., Chardon, D., Rouby, D., Guillocheau, F., Dall Asta, M., Ferry, J., \& Broucke, O. (2017). Paleogeographic and structural evolution of northwestern Africa and its Atlantic margins since the early Mesozoic. Geosphere, 13(4), 1254-1284. https://doi.org/10.1130/GES01426.1

Ye, Q., Mei, L., Shi, H., Shu, Y., Camanni, G., \& Wu, J. (2018). A low-angle normal fault and basement structures within the Enping Sag, Pearl River Mouth Basin: Insights into late Mesozoic to early Cenozoic tectonic evolution of the South China Sea area. Tectonophysics, 731-732, 1-16. https://doi.org/10.1016/j.tecto.2018.03.003

YM (Yingcheng Map) (1976). 1:200000 Geological Map of the People's Republic of China. Yingcheng Region (in Chinese).

Zhang, Y., Xu, X., Jia, D., \& Shu, L. (2009). Deformation record of the change from Indosinian collision-related tectonic system to Yanshanian subduction-related tectonic system in South China during the Early Mesozoic. Earth Science Frontiers, 16(1), 234-247. (in Chinese with English abstract)

ZM (Zhongxiang Map) (1976). 1:200 000 Geological Map of the People's Republic of China, Zhongxiang Region (in Chinese). 